\title{
Review:
}

\section{Progress in the aqueous-phase reforming of different biomass-derived alcohols for hydrogen production}

\author{
Guan-yi CHEN ${ }^{1}$, Wan-qing $\mathrm{LI}^{1,2}$, Hong $\mathrm{CHEN}^{\dagger+1}$, Bei-bei $\mathrm{YAN}^{1,3}$ \\ $\left({ }^{1}\right.$ School of Environmental Science and Engineering, Tianjin University, Tianjin 300072, China) \\ $\left({ }^{2}\right.$ Provincial Key Lab of Forestry and Ecological Environment, Beihua University, Jilin 132013, China) \\ $\left({ }^{3}\right.$ MOE Key Laboratory of Efficient Utilization of Low and Medium Grade Energy, Tianjin University, Tianjin 300072, China) \\ †E-mail: chenhong_0405@tju.edu.cn \\ Received Jan. 31, 2015; Revision accepted Apr. 6, 2015; Crosschecked May 13, 2015
}

\begin{abstract}
Hydrogen as a clean, efficient, and sustainable energy has attracted considerable attention in recent years. Hydrogen production from aqueous-phase reforming (APR) of biomass-derived alcohols is preferable to other methods because of its wide renewable resource, mild reaction conditions, and low processing cost. In this paper, the progress in the APR process of different biomass-derived alcohols for $\mathrm{H}_{2}$ production is reviewed, and the reaction mechanisms are briefly discussed for different catalysts. Pt-based catalysts exhibit high $\mathrm{H}_{2}$ selectivity but low conversion of the alcohols. Ni-based catalysts exhibit high activity and conversion but low $\mathrm{H}_{2}$ selectivity and yield.
\end{abstract}

Key words: Biomass, Alcohols, Hydrogen production, Aqueous-phase reforming (APR), Reaction mechanism, Catalysts doi:10.1631/jzus.A1500023

Document code: A

CLC number: TQ116.2

\section{Introduction}

Because of increasing fossil fuel consumption and its associated serious environmental pollution, hydrogen, a clean, quiet, and highly efficient energy with a flexible number of applications, including power generation, calorification, and power automobiles, has received wide attention. Hydrogen can be obtained through fossil fuels by various techniques. Currently, almost $97 \%$ of hydrogen is made by reforming fossil fuels, including natural gas, oil, coal, and naphtha, which will lead to a high carbon footprint. Further, hydrogen production by means of a

\footnotetext{
Corresponding author

* Project supported by the National Basic Research Program (973 Program) of China (No. 2012CB215303), and the Science Research Foundation of Shandong Entry-Exit Inspection and Quarantine Bureau of China (No. SK201042)

(10) ORCID: Guan-yi CHEN, http://orcid.org/0000-0003-4311-5708; Hong CHEN, http://orcid.org/0000-0002-0325-2786

(c) Zhejiang University and Springer-Verlag Berlin Heidelberg 2015
}

water electrolysis method usually results in immense power consumption.

Hydrogen can also be produced from renewable sources such as solar energy, wind energy, hydropower, nuclear energy, and biomass. In contrast, some unique characteristics of biomass, including large storage capacity, low price, great potential for commercialization, carbon neutral, and mild reaction condition, make it feasible for hydrogen production. However, current methods for hydrogen production require immense power consumption, high temperature and pressure. Aqueous-phase reforming (APR), proposed by Dumesic (Cortright et al., 2002), generated hydrogen and alkanes from biomass-derived resources in liquid water. The major advantages of the APR process include three aspects. First, this process is applicable for either wet or water soluble feedstock. Second, owing to the superiority of the water-gas shift (WGS) reaction, the production of $\mathrm{CO}$, which is a major byproduct, can be reduced effectively (Davda et al., 2005). Third, compared with conventional alkane stream reforming processes, this 
reforming process is performed at a relatively low temperature (i.e., $500 \mathrm{~K}$ ) and elevated pressure (i.e., $2.5 \mathrm{MPa}$ ). Notably, these conditions preclude the evaporation of water. To date, the model compounds that have been studied include methanol, ethanol, ethylene glycol, glycerol, butanol, sorbitol, mannitol, and xylitol. Research on the catalysts used in the APR process is also an active area.

In this paper, the research progress of the APR of alcohols for hydrogen production is reviewed. We also discuss the use of different alcohols as substrates for these reactions. Additionally, perspectives to the future for hydrogen production are briefly examined.

\section{Mechanism of the aqueous-phase reform- ing of alcohols}

In 2002, Dumesic (Cortright et al., 2002) proposed catalytic bio-conversion and bio-refinery methods to obtain hydrogen, thus making a breakthrough in hydrogen generation. Hydrogen was produced through a direct biomass reforming reaction at $550 \mathrm{~K}$ by using aqueous-phase sugar and alcohols as the raw materials. The entire reaction is performed in the aqueous phase whereby cellulose and hemicellulose are reduced to sugar via hydrolyzation with the assistance of heat and acid. Then, the sugar is used as a workable feedstock in biological fermentation processes. Thus, an aqueous-phase biomass reforming process such as this could result in a higher biomass utilization rate compared to physical, chemical or biological methods (Cortright et al., 2002; Huber et al., 2003; 2006; Davda et al., 2005).

For example, the alcohols can be reformed to produce $\mathrm{H}_{2}$ and $\mathrm{CO}_{2}$ through the following reaction (Huber et al., 2004):

$$
\mathrm{C}_{n} \mathrm{H}_{2 n+2} \mathrm{O}_{n}+n \mathrm{H}_{2} \mathrm{O} \rightarrow n \mathrm{CO}_{2}+(2 n+1) \mathrm{H}_{2} .
$$

$\mathrm{CO}$ and $\mathrm{H}_{2}$ can be formed by breaking $\mathrm{C}-\mathrm{C}$ bonds. Then, $\mathrm{CO}$ will react with $\mathrm{H}_{2} \mathrm{O}$ to produce $\mathrm{CO}_{2}$ and $\mathrm{H}_{2}$ by WGS reaction:

$$
\mathrm{CO}+\mathrm{H}_{2} \mathrm{O} \rightarrow \mathrm{CO}_{2}+\mathrm{H}_{2}
$$

Some secondary reactions will also occur when the formation of $\mathrm{H}_{2}$ and $\mathrm{CO}_{2}$ by the APR method is performed at relatively low temperatures. For example, $\mathrm{CO}_{2}$ and $\mathrm{H}_{2}$ will be converted to methane at $500 \mathrm{~K}$ through the methanation and Fischer-Tropsch reactions (Vannice, 1977; Kellner and Bell, 1981; Dixit and Tavlarides, 1983; Iglesia et al., 1992):

$$
\begin{aligned}
& 3 \mathrm{H}_{2}+\mathrm{CO} \rightarrow \mathrm{CH}_{4}+\mathrm{H}_{2} \mathrm{O}, \\
& 4 \mathrm{H}_{2}+\mathrm{CO}_{2} \rightarrow \mathrm{CH}_{4}+2 \mathrm{H}_{2} \mathrm{O}, \\
& n \mathrm{CO}+2 n \mathrm{H}_{2} \rightarrow\left[-\mathrm{CH}_{2}-\right] n+n \mathrm{H}_{2} \mathrm{O} .
\end{aligned}
$$

Fig. 1 shows an outline of the APR process, the $\mathrm{H}_{2}$ formation paths and the production of alkanes from alcohols. First, the alcohols transform into the adsorbed intermediates on the catalyst surface after dehydrogenation steps, followed by cleavage of the $\mathrm{C}-\mathrm{C}$ or $\mathrm{C}-\mathrm{O}$ bonds. Second, the optimal situation is that cleavage of the $\mathrm{C}-\mathrm{C}$ bonds is followed by the WGS reaction, which will produce $\mathrm{H}_{2}$. However, the scission of C-O bonds will possibly make organic acids, which are stable and cannot be reformed easily. Moreover, the produced organic acids can corrode the equipment and inactivate the catalysts (Davda et al., 2003). Therefore, effective catalysts for the APR process should demonstrate high activity in cleaving $\mathrm{C}-\mathrm{C}$ bonds, high capacity to promote the subsequent WGS reaction, and low activity in the methanation reactions. The present studies on the APR of biomass-derived alcohols for hydrogen production focus on promoting the catalytic activity.

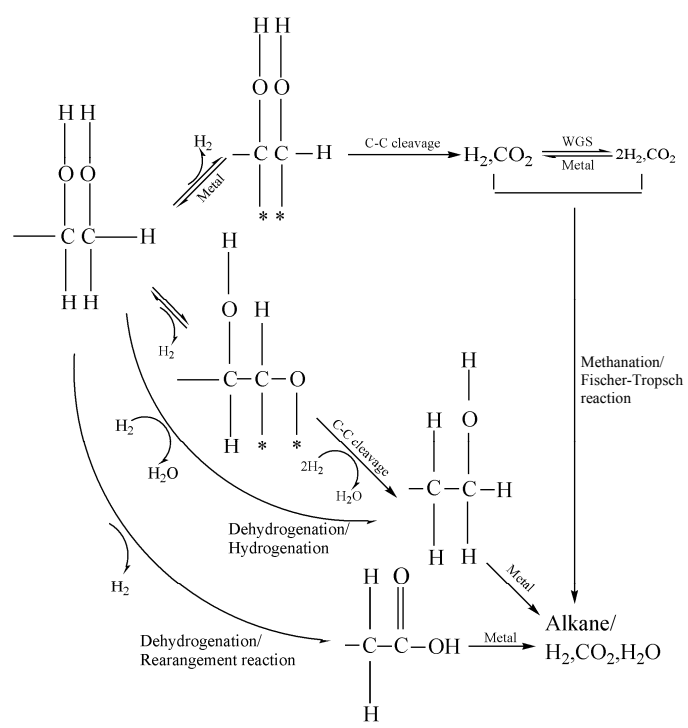

Fig. 1 Reaction pathways for production of $\mathrm{H}_{2}$ by an aqueous-phase reforming process

Reprinted from (Davda et al., 2003), Copyright 2003, with permission from Elsevier 


\section{Hydrogen production from the aqueous- phase reforming of biomass-derived alcohols}

Many biomass-derived alcohols, such as methanol, sorbitol, glycerol, butanol, and ethylene glycol, have been used in APR process for $\mathrm{H}_{2}$ production (Cortright et al., 2002; Davda et al., 2005). Different catalysts were used in these systems. The performances of noble metal catalysts, non-noble metal catalysts, and different supports strongly affected the efficacy of these catalysts. More specifically, the chemical state and load of the catalyst are the primary factors that influence the activity of these catalysts.

\subsection{Aqueous-phase reforming of ethylene glycol}

In early studies, ethylene glycol was mainly a feed molecule for the APR process. It possesses the typical structure of alcohols including $\mathrm{C}-\mathrm{C}, \mathrm{C}-\mathrm{O}$, $\mathrm{C}-\mathrm{H}, \mathrm{O}-\mathrm{H}$ bonds, and $\mathrm{OH}$ groups. The production of $\mathrm{CO}$ is favorable, and can undergo a methanation or Fischer-Tropsch synthesis to produce alkanes. Alternatively, ethylene glycol can be converted to $\mathrm{H}_{2}$ and $\mathrm{CO}_{2}$ by the WGS reaction, or even react with $\mathrm{H}_{2}$ to form methanol. Ethylene glycol can also generate acetic acid by dehydrogenation or isomerization, or via an acetaldehyde intermediate (Fig. 2).

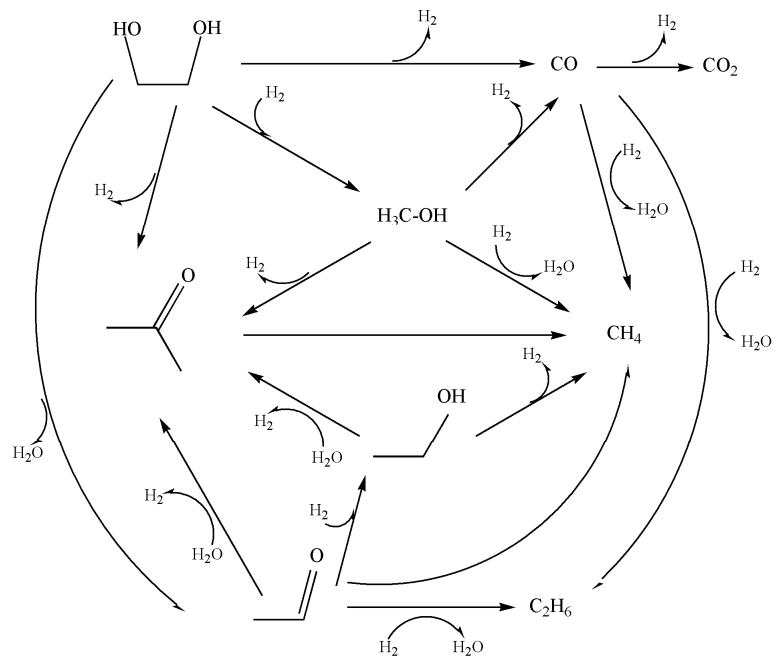

Fig. 2 Reaction pathways for ethylene glycol reforming (Reprinted from (Shabaker and Dumesic, 2004), Copyright 2004, with permission from American Chemical Society)

Different types of catalysts were applied in the APR of ethylene glycol, including noble metal-based catalysts, such as Pt, Pd, Rh, Ru, and Ir (Liu et al.,
2008; Skoplyak et al., 2009; Kim et al., 2011; 2012a), Sn modified Raney Ni (Huber et al., 2003; Shabaker and Dumesic, 2004; Shabaker et al., 2004; 2005), NiMgAl layered double hydroxide catalysts, $\mathrm{Ni} / \mathrm{Sn} / \mathrm{Al}$ hydrotalcite derived catalysts (Pan et al., 2012), rapidly quenched skeletal $\mathrm{Ni}$ (Xie et al., 2006), non-pyrophoric Ni catalysts (Zhu et al., 2008), and $\mathrm{Co} / \mathrm{ZnO}$ catalysts (Chu et al., 2011).

\subsubsection{Noble metal catalysts}

Davda et al. (2003) tested the catalytic activity of the catalysts $\mathrm{Ni}, \mathrm{Pd}, \mathrm{Pt}, \mathrm{Ru}, \mathrm{Rh}$, and Ir supported on silica for the APR of ethylene glycol, and found that the activity decreased in the following order: $\mathrm{Pt} \sim \mathrm{Ni}>\mathrm{Ru}>\mathrm{Rh}>\mathrm{Pd}>\mathrm{Ir}$. All of the $\mathrm{H}_{2}$ selectivity on $\mathrm{Rh}$, $\mathrm{Ru}$, and $\mathrm{Ni} / \mathrm{SiO}_{2}$ was low, whereas the alkane selectivity was high. In contrast, it was found that $\mathrm{Pt}$ and Pd catalysts supported on silica presented higher $\mathrm{H}_{2}$ selectivity and lower alkane selectivity.

Among all of the noble metal utilized in the APR, Pt consistently demonstrates higher hydrogen selectivity. Kim et al. (2011) examined a series of Pt-based catalysts supported on ordered mesoporous carbon (CMK-3) with different Pt loadings. The catalytic performance of these materials with different supported catalysts for the APR reaction is shown in Table 1. The optimal Pt loading with the highest hydrogen production rates was 7\% (in weight, unless otherwise stated) for CMK-3, which results from the high dispersion of Pt nanoparticles, good hydrothermal stability, and a 3D highly opened mesoporous structure. The catalytic performance would be enhanced by a Pt catalyst supported on a hollow-type ordered mesoporous carbon (OMC) with a 3D pore structure because of the synergetic effect between the low amount of metal sintering during the reaction process and the favorable transport and diffusion of the reactants and products (Kim et al., 2012b; Jeong et al., 2014).

A support improves the metal dispersion of a supported catalyst. The promoter is also very important. In the APR reaction, not only the nature of the support has an influence on the activity but also the distribution of the products on the surface affects the activity. Kim et al. $(2011 ; 2012$ a) examined the APR catalytic activity over monometallic Pt catalysts and bimetallic Pt-Mn catalysts on different supports. The hydrogen production rates among 
these catalysts followed the order: $\mathrm{Pt} / \mathrm{CMK}-3>$ $\mathrm{Pt} /$ activated carbon $(\mathrm{AC})>\mathrm{Pt} / \gamma-\mathrm{Al}_{2} \mathrm{O}_{3}>\mathrm{Pt} /$ Catapal $\mathrm{B}$. Relative to oxide-based catalysts, the stability of carbon-based catalysts under severe hydrothermal reactions leads to superior hydrogen production than alumina-based supports. These data suggest that the catalytic activity of APR is affected greatly by the structural properties of the supports. Kim et al. (2012c) made similar conclusions. The activity of supported catalysts followed the order: CMK-3> $\mathrm{AC}>\mathrm{SiO}_{2}>\mathrm{Al}_{2} \mathrm{O}_{3}$. The reaction data of the Pt-based catalysts on different supports are listed in Table 2. Both carbon-based catalysts (i.e., $\mathrm{CMK}-3$ and $\mathrm{AC}$ ) showed higher $\mathrm{H}_{2}$ yield than the $\mathrm{Al}_{2} \mathrm{O}_{3}$ and $\mathrm{SiO}_{2}$ catalysts, which is because of the high surface area and thermal stability of the carbon-based catalysts relative to the oxide-based catalysts. In addition, a higher $\mathrm{H}_{2}$ yield and ethylene glycol conversion on the carbon-based catalysts indicated that the metal oxide supports sintered during the APR reaction because of their weak hydrothermal stability at high temperatures. Finally, for the $\mathrm{Al}_{2} \mathrm{O}_{3}$ support, in situ generation of the acid sites formed the $\mathrm{H}_{2}$ spillover, and the high acidity of $\mathrm{Al}_{2} \mathrm{O}_{3}$ led to low $\mathrm{H}_{2}$ formation and high alkane selectivity. Additionally, Liu et al. (2008) synthetized a Pt-based Fe-Cr catalyst. The X-ray diffraction (XRD) results demonstrated that the addition of $\mathrm{Cr}$ could promote the phase

Table 1 Catalytic performance of APR over different Pt-based catalysts

\begin{tabular}{|c|c|c|c|c|c|c|c|c|c|}
\hline \multirow{2}{*}{ Catalyst } & \multirow{2}{*}{$\begin{array}{c}\text { Loading } \\
(\%)\end{array}$} & \multirow{2}{*}{$\begin{array}{c}\text { Conversion } \\
(\%)\end{array}$} & \multirow{2}{*}{$\begin{array}{c}\mathrm{H}_{2} \text { yield } \\
(\%)\end{array}$} & \multirow{2}{*}{$\begin{array}{c}\text { Alkane } \\
\text { selectivity }(\%)\end{array}$} & \multicolumn{4}{|c|}{ Gas products $(\%)$} & \multirow{2}{*}{ Reference } \\
\hline & & & & & $\mathrm{H}_{2}$ & $\mathrm{CO}_{2}$ & $\mathrm{CO}$ & Alkanes & \\
\hline $\mathrm{Pt} / \mathrm{CMK}-3$ & 1 & 32.5 & 24.9 & 5.0 & 65.8 & 32.7 & $\mathrm{ND}^{\mathrm{a}}$ & 1.5 & \multirow{5}{*}{$\begin{array}{c}\text { Kim et al., } \\
2011^{\mathrm{b}}\end{array}$} \\
\hline $\mathrm{Pt} / \mathrm{CMK}-3$ & 2 & 41.8 & 32.2 & 3.3 & 65.9 & 33.1 & $\mathrm{ND}^{\mathrm{a}}$ & 1.0 & \\
\hline $\mathrm{Pt} / \mathrm{CMK}-3$ & 5 & 59.1 & 43.9 & 4.3 & 66.1 & 32.5 & $\mathrm{ND}^{\mathrm{a}}$ & 1.4 & \\
\hline $\mathrm{Pt} / \mathrm{CMK}-3$ & 7 & 75.8 & 56.7 & 6.8 & 65.4 & 32.6 & $\mathrm{ND}^{\mathrm{a}}$ & 2.0 & \\
\hline $\mathrm{Pt} / \mathrm{CMK}-3$ & 10 & 79.4 & 57.5 & 6.5 & 64.7 & 33.3 & $\mathrm{ND}^{\mathrm{a}}$ & 2.0 & \\
\hline $\mathrm{Pt} / \mathrm{CMK}-3$ & 7 & 69.8 & 72.1 & 7.1 & 71.0 & 27.6 & $\mathrm{ND}^{\mathrm{a}}$ & 1.5 & \multirow{4}{*}{$\begin{array}{c}\text { Kim et al., } \\
2012 b^{b}\end{array}$} \\
\hline $\mathrm{Pt} / \mathrm{CMK}-5$ & 7 & 79.5 & 77.0 & 5.7 & 71.2 & 27.3 & $\mathrm{ND}^{\mathrm{a}}$ & 1.4 & \\
\hline $\mathrm{Pt} / \mathrm{CMK}-8$ & 7 & 85.8 & 84.7 & 4.7 & 71.4 & 27.4 & $\mathrm{ND}^{\mathrm{a}}$ & 1.2 & \\
\hline $\mathrm{Pt} / \mathrm{CMK}-9$ & 7 & 89.2 & 94.2 & 4.4 & 72.1 & 27.0 & $\mathrm{ND}^{\mathrm{a}}$ & 0.9 & \\
\hline $\mathrm{Pt} / \mathrm{CMK}-3-\mathrm{MCM}$ & 7 & 78.6 & 60.4 & 16.1 & 66.2 & 28.9 & $\mathrm{ND}^{\mathrm{a}}$ & 4.9 & \multirow{4}{*}{$\begin{array}{c}\text { Jeong et al. } \\
2014^{\mathrm{b}}\end{array}$} \\
\hline Pt/CMK-3-MCN-R & 7 & 84.7 & 71.7 & 6.1 & 68.1 & 30.2 & $\mathrm{ND}^{\mathrm{a}}$ & 1.7 & \\
\hline $\mathrm{Pt} / \mathrm{CMK}-5-\mathrm{MCM}$ & 7 & 83.0 & 76.8 & 5.3 & 70.0 & 28.7 & $\mathrm{ND}^{\mathrm{a}}$ & 1.4 & \\
\hline Pt/CMK-5-MCN-R & 7 & 88.0 & 86.3 & 5.9 & 71.2 & 27.3 & $\mathrm{ND}^{\mathrm{a}}$ & 1.3 & \\
\hline
\end{tabular}

${ }^{a} \mathrm{ND}$ : not detected (below the gas chromatography (GC) detection limit); ${ }^{\mathrm{b}}$ Reaction conditions: $10 \%$ ethylene glycol, $523 \mathrm{~K}, 4.56 \mathrm{MPa}$, weight hourly space velocity (WHSV) of $2.0 \mathrm{~h}^{-1}, 24 \mathrm{~h}$

Table 2 Catalytic performance of different supported Pt-based catalysts in the APR of $10 \%$ ethylene glycol

\begin{tabular}{|c|c|c|c|c|c|c|}
\hline Catalyst & $\begin{array}{c}\text { Loading } \\
(\%)\end{array}$ & $\begin{array}{c}\text { Conversion } \\
(\%)\end{array}$ & $\begin{array}{c}\mathrm{H}_{2} \text { production rate } \\
\left(\mathrm{cm}^{3} /\left(\mathrm{g}_{\text {cat }} \cdot \min \right)\right)\end{array}$ & $\begin{array}{c}\mathrm{H}_{2} \text { yield } \\
(\%)\end{array}$ & $\begin{array}{c}\text { Alkanes } \\
\text { selectivity (\%) }\end{array}$ & Reference \\
\hline $\mathrm{Pt} / \mathrm{CMK}-3$ & 7 & 75.8 & 37.8 & 56.7 & 6.8 & \multirow{4}{*}{$\begin{array}{l}\text { Kim et al., } \\
\qquad 2011^{\mathrm{a}}\end{array}$} \\
\hline $\mathrm{Pt} / \mathrm{AC}$ & 7 & 38.1 & 18.0 & 27.0 & 5.8 & \\
\hline $\mathrm{Pt} / \gamma-\mathrm{Al}_{2} \mathrm{O}_{3}$ & 7 & 38.6 & 14.3 & 21.5 & 10.8 & \\
\hline Pt/Catapal B & 7 & 25.4 & 10.1 & 15.1 & 7.4 & \\
\hline Pt-Mn/CMK-3 & 1 & 39.7 & 26.8 & 40.2 & 2.9 & \multirow{3}{*}{$\begin{array}{l}\text { Kim et al., } \\
2012 \mathrm{a}^{\mathrm{a}}\end{array}$} \\
\hline $\mathrm{Pt}-\mathrm{Mn} / \mathrm{AC}$ & 1 & 34.2 & 22.7 & 34.1 & 5.5 & \\
\hline $\mathrm{Pt}-\mathrm{Mn} / \gamma-\mathrm{Al}_{2} \mathrm{O}_{3}$ & 1 & 27.7 & 19.6 & 29.4 & 3.8 & \\
\hline Pt-Re/CMK-3 & 3 & 89.3 & 36.6 & 55.0 & 26.4 & \multirow{4}{*}{$\begin{array}{l}\text { Kim et al. } \\
2012 c^{a}\end{array}$} \\
\hline $\mathrm{Pt}-\mathrm{Re} / \mathrm{AC}$ & 3 & 80.0 & 30.4 & 45.7 & 29.2 & \\
\hline $\mathrm{Pt}-\mathrm{Re} / \mathrm{Al}_{2} \mathrm{O}_{3}$ & 3 & 43.8 & 22.4 & 33.7 & 12.9 & \\
\hline $\mathrm{Pt}-\mathrm{Re} / \mathrm{SiO}_{2}$ & 3 & 63.1 & 25.9 & 38.9 & 25.2 & \\
\hline
\end{tabular}

${ }^{a}$ Reaction conditions: $523 \mathrm{~K}, 4.56 \mathrm{MPa}$, WHSV of $2.0 \mathrm{~h}^{-1}$ 
composition of iron oxide, and the formation of amorphous $\mathrm{Cr}$ oxides improved the BET surface area of $\mathrm{Fe}-\mathrm{Cr}$ mixed oxides.

The addition of other metals to Pt-based catalysts is growing interest. The cost of the catalyst might be reduced while maintaining the catalytic activity. As in the case of Kim et al. (2012a), a series of metal were doped on Pt-based catalysts. The activities of these catalysts are shown in Table 3. The rate of hydrogen production and hydrogen yield decreased in the following order: Pt-Mn $>\mathrm{Pt}-\mathrm{Fe}>$ Pt-Re $>$ Pt $>$ Pt-Cs $>$ Pt-Ba $>$ Pt-Ga $>$ Pt-Mo $>$ Pt-Ag. $\quad$ The addition of $\mathrm{Mn}$ to a Pt-based catalyst had a higher catalytic activity than the Pt/CMK-3 catalyst. This indicated that $\mathrm{Mn}$ could increase the reduction behavior and consequent alloy formation that was responsible for the enhancement of the catalytic activity in the APR, especially for the hydrogen production rate. Bai et al. (2006) utilized the Pt-Ce/ $\gamma-\mathrm{Al}_{2} \mathrm{O}_{3}$ and Pt-Mg/ $\gamma-\mathrm{Al}_{2} \mathrm{O}_{3}$ catalysts in the APR of ethylene glycol. It was suggested that both bimetallic catalysts showed higher catalytic activities than $\mathrm{Pt} / \gamma-\mathrm{Al}_{2} \mathrm{O}_{3}$, and the conversion of ethylene glycol was increased from $72.3 \%$ to $100 \%$ with an almost $100 \% \mathrm{H}_{2}$ selectivity. The presence of $\mathrm{Ce}$ increased the dispersion of $\mathrm{Pt}$ on the surface of $\gamma-\mathrm{Al}_{2} \mathrm{O}_{3}$ and improved the adsorption cracking of ethylene glycol on $\mathrm{Pt}$ and the WGS reaction. At the same time, the presence of $\mathrm{Mg}$ could neutralize the acidity of $\gamma-\mathrm{Al}_{2} \mathrm{O}_{3}$, promote the dispersion of $\mathrm{PtAl}_{6}^{2-}$, and inhibit the dehydration of ethylene glycol. de Vlieger et al. (2012) found that the formation of acetic acid could be suppressed by Pt-Ni catalyst during the APR of ethylene glycol, and the $\mathrm{H}_{2}$ selectivity and catalyst lifetime would be increased. Huber et al. (2006) suggested that alloying $\mathrm{Pt}$ with either $\mathrm{Ni}$, Co or $\mathrm{Fe}$ could promote the activity for hydrogen production by decreasing the heats of adsorption of $\mathrm{CO}$ and hydrogen, which

Table 3 Effect of doped metals on the catalytic activity of ethylene glycol APR

\begin{tabular}{|c|c|c|c|c|c|}
\hline Catalyst & Proportion of Pt-M & $\begin{array}{c}\text { Conversion } \\
(\%)\end{array}$ & $\begin{array}{c}\mathrm{H}_{2} \text { production rate } \\
\left(\mathrm{cm}^{3} /\left(\mathrm{g}_{\text {cat }} \cdot \min \right)\right)\end{array}$ & $\begin{array}{c}\text { Alkanes selectivity } \\
(\%)\end{array}$ & Reference \\
\hline Pt-Re/CMK-3 & $1: 1$ & 44.2 & 19.9 & 19.8 & \multirow{9}{*}{ Kim et al., 2012a $\mathrm{a}^{\mathrm{a}}$} \\
\hline Pt-Mn/CMK-3 & $1: 1$ & 39.7 & 26.8 & 2.9 & \\
\hline $\mathrm{Pt}-\mathrm{Fe} / \mathrm{CMK}-3$ & $1: 1$ & 30.4 & 22.1 & 2.0 & \\
\hline $\mathrm{Pt}-\mathrm{Cs} / \mathrm{CMK}-3$ & $1: 1$ & 20.1 & 12.5 & 1.5 & \\
\hline $\mathrm{Pt}-\mathrm{Ba} / \mathrm{CMK}-3$ & $1: 1$ & 15.3 & 10.6 & 2.7 & \\
\hline Pt-Ga/CMK-3 & $1: 1$ & 5.7 & 5.5 & 3.85 & \\
\hline Pt-Ag/CMK-3 & $1: 1$ & 0.2 & 0.3 & 0 & \\
\hline Pt-Mo/CMK-3 & $1: 1$ & 5.8 & 3.1 & 18.9 & \\
\hline $\mathrm{Pt}$ & $1: 0$ & 25.4 & 17.7 & 4.5 & \\
\hline $\mathrm{Pt}-\mathrm{Mg} / \gamma-\mathrm{Al}_{2} \mathrm{O}_{3}$ & 1.79 & 100 & 1.2 & - & \multirow{2}{*}{ Bai et al., 2006 } \\
\hline $\mathrm{Pt}-\mathrm{Ce} / \gamma-\mathrm{Al}_{2} \mathrm{O}_{3}$ & 1.82 & 100 & 1.3 & - & \\
\hline $\mathrm{Pt}-\mathrm{Ni} / \gamma-\mathrm{Al}_{2} \mathrm{O}_{3}$ & 3.29 & 80 & - & - & $\begin{array}{l}\text { Vliegar et al., } \\
2012^{\mathrm{c}}\end{array}$ \\
\hline $\mathrm{Pt}-\mathrm{Ni} / \gamma-\mathrm{Al}_{2} \mathrm{O}_{3}$ & 1 & 3.9 & 0.60 & 0.0 & \multirow{11}{*}{$\begin{array}{l}\text { Huber et al., } \\
\qquad 2006^{\mathrm{d}}\end{array}$} \\
\hline $\mathrm{Pt}-\mathrm{Ni} / \gamma-\mathrm{Al}_{2} \mathrm{O}_{3}$ & 0.2 & 2.3 & 0.07 & 0.0 & \\
\hline $\mathrm{Pt}-\mathrm{Ni} / \gamma-\mathrm{Al}_{2} \mathrm{O}_{3}$ & 0.125 & 3.0 & 0.84 & 1.2 & \\
\hline $\mathrm{Pt}-\mathrm{Co} / \gamma-\mathrm{Al}_{2} \mathrm{O}_{3}$ & 0.2 & 3.8 & 0.50 & 0.0 & \\
\hline $\mathrm{Pt}-\mathrm{Co} / \gamma-\mathrm{Al}_{2} \mathrm{O}_{3}$ & 0.11 & 3.6 & 0.06 & 0.0 & \\
\hline $\mathrm{Pt}-\mathrm{Ni} / \gamma-\mathrm{Al}_{2} \mathrm{O}_{3}$ & 1 & 5.9 & 0.96 & 0.0 & \\
\hline $\mathrm{Pt}-\mathrm{Ni} / \gamma-\mathrm{Al}_{2} \mathrm{O}_{3}$ & 0.2 & 3.6 & 1.12 & 0.9 & \\
\hline $\mathrm{Pt}-\mathrm{Ni} / \gamma-\mathrm{Al}_{2} \mathrm{O}_{3}$ & 0.125 & 3.5 & 1.01 & 2.0 & \\
\hline $\mathrm{Pt}-\mathrm{Co} / \gamma-\mathrm{Al}_{2} \mathrm{O}_{3}$ & 0.2 & 8.4 & 0.93 & 0.5 & \\
\hline $\mathrm{Pt}-\mathrm{Fe} / \gamma-\mathrm{Al}_{2} \mathrm{O}_{3}$ & 0.11 & 26.9 & 0.03 & 0.0 & \\
\hline $\mathrm{Pt}-\mathrm{Fe} / \gamma-\mathrm{Al}_{2} \mathrm{O}_{3}$ & 0.11 & 48.1 & 0.06 & 1.1 & \\
\hline Pt-Re/CMK-3 & 1 & 89.3 & 36.6 & - & Kim et al., 2012 $\mathrm{c}^{\mathrm{e}}$ \\
\hline
\end{tabular}

Reaction conditions: ${ }^{a} 10 \%$ ethylene glycol, $523 \mathrm{~K}, 4.56 \mathrm{MPa} ;{ }^{\mathrm{b}} 10 \%$ ethylene glycol, $498 \mathrm{~K}, 2.58 \mathrm{MPa} ;{ }^{\mathrm{c}} 1 \%$ ethylene glycol, $458 \mathrm{~K}$, $2.0 \mathrm{MPa} ;{ }^{\mathrm{d}} 10 \%$ ethylene glycol, $483 \mathrm{~K}, 2.54 \mathrm{MPa} ;{ }^{\mathrm{e}} 10 \%$ ethylene glycol, $523 \mathrm{~K}, 4.58 \mathrm{MPa}$ 
would increase the fraction of the surface available for its reaction with ethylene glycol. Dispersion of Pt on the supports could be improved by the addition of Re or Co (Wang et al., 2009; Kim et al., 2012c). The Pt-Re/CMK-3 catalyst has much higher activity on the APR of ethylene glycol. The Pt-Co/single-walled carbon nanotube bimetallic catalyst obtained by sequential impregnation exhibited a core-shell structure with $\mathrm{Co}$ as the core and a Pt-Co alloy phase as the shell, where $\mathrm{Pt}$ was atomically dispersed and $\mathrm{Co}$ acted as a co-catalyst or promoter.

\subsubsection{Non-noble metal catalysts}

Although noble metal-based catalysts such as $\mathrm{Pt} / \gamma-\mathrm{Al}_{2} \mathrm{O}_{3}$ demonstrated high catalytic activity and $\mathrm{H}_{2}$ selectivity, their expense limits their technological viability. Therefore, numerous studies have been performed to search for inexpensive materials with good catalytic characteristics for the APR process.

Chu et al. (2011) prepared $\mathrm{Co} / \mathrm{ZnO}$ catalysts with four different $\mathrm{Co} / \mathrm{Zn}$ molar ratios by the coprecipitation method. The APR experiments showed that the catalyst activity and the $\mathrm{H}_{2}$ selectivity increased with the amount of $\mathrm{ZnO}$, and there was much less $\mathrm{CO}$ in the gas products. Moreover, the bimetallic catalysts showed high catalytic activity in the APR process.

Chu et al. (2009) reported that the addition of Sn had a remarkable effect not only on the chemical composition, texture, and structure of the catalyst but also on its active site. The Sn modified catalyst had a higher hydrogen production rate and selectivity, and the formation of alkanes was substantially suppressed. Pan et al. (2012) proposed that Sn existed in a $\mathrm{SnO}$ phase on the $\mathrm{Ni} / \mathrm{Sn} / \mathrm{Al}$ hydrotalcite catalyst synthesized by a co-precipitation method. $\mathrm{Ni}_{20} \mathrm{SnAl}_{7-}$ hydrotalcites showed a good $\mathrm{H}_{2}$ selectivity of nearly $100 \%$ and a good catalytic stability over $120 \mathrm{~h}$.

The main research was focused on the noble catalyst with high $\mathrm{H}_{2}$ selectivity and high ethylene glycol conversion. Because ethylene glycol is more difficult to convert and the APR process requires a water-resistance catalyst, most oxide-based materials cannot function properly when $\mathrm{H}_{2} \mathrm{O}$ is at high temperatures. Ethanol is easier to convert under the same conditions. Thus, the application of bio-ethanol has become more important in biomass applications. Consequently, research into ethanol APR has increased in importance.

\subsection{Aqueous-phase reforming of ethanol for hy- drogen production}

Bio-ethanol is widely used as the substrate in the production of hydrogen because it is a direct product from the fermentation process of the biomass. In addition, bio-ethanol has high hydrogen content and is nontoxic. The $\mathrm{CO}_{2}$ generated during the hydrogen production process can be consumed by the photosynthesis of the biomass growth, which is formed in a $\mathrm{CO}_{2}$ cycle.

There are many methods available for hydrogen production by using ethanol as the substrate, including steam reforming, oxidative reforming, and autothermal catalytic reforming. However, these methods possess many drawbacks, such as high reaction temperatures $(573-873 \mathrm{~K})$, incomplete WGS reactions, high $\mathrm{CO}$ concentrations in the gas products $(5 \%-$ $20 \%$ ), complicated equipment for $\mathrm{H}_{2}$ purification, low ethanol conversion, $\mathrm{H}_{2}$ selectivity, and alkylation side reactions. For these reasons, APR of ethanol for hydrogen production has been investigated because of its modest and straightforward reaction conditions.

\subsubsection{Noble metal catalysts}

In the APR of ethanol, a noble metal, such as Pt, is always used as the catalyst. Tokarev et al. (2010) utilized a $\mathrm{Pt} / \mathrm{Al}_{2} \mathrm{O}_{3}$ catalyst in the APR process of bio-ethanol to produce hydrogen, and they compared its efficiency by using glycerol and sorbitol as the substrates. The results showed that ethanol conversion could reach $98.3 \%$ and that methane will be formed from the ethanol transformation.

$$
\widehat{\mathrm{OH}}+\mathrm{H}_{2} \mathrm{O} \rightarrow \mathrm{CH}_{4}+\mathrm{CO}_{2}+2 \mathrm{H}_{2} .
$$

Only ethanol and acetic acid were detected in the liquid products. When there was glycerol or sorbitol in the substrate, similar amounts of acetic acid and acetaldehyde were present, though they were lower than the quantities present in the reaction that used only ethanol as the substrate. The conversion of ethanol with APR was high, but the hydrogen yield decreased when there was either a fraction or full measures of glycerol and sorbitol in the substrate. The amounts of acetic acid and acetaldehyde were similar, which are much lower than the ethanol concentration present in glycerol or sorbitol. This is 
because of the inhibition of ethanol for converting aldehydes to hemiacetals and acetals. Consequently, aldehydes could not be concentrated to form larger by-products.

\subsubsection{Non-noble metal catalysts}

The industrial application of noble metal catalysts was limited by its high cost. For this reason, the development of nickel catalysts has attracted more attention in recent years. Roy et al. (2010) prepared a $\mathrm{Ni} / \mathrm{Al}_{2} \mathrm{O}_{3}$ catalyst by a solution combustion synthesis method, and modified its surface using a nonthermal radio frequency (RF) plasma. Liu et al. (2002) found that the surface modification could reduce the energy requirements and shorten the preparation time without altering the bulk properties of the catalyst. In addition, it has been reported that such modifications could: i) avoid the particles sintering, ii) increase the activity of the catalyst, iii) promote the metal dispersion, and iv) improve the stability of the catalyst by restraining carbon deposition on its surface, which would prolong its lifetime (Dadashova et al., 1991; 1993; Yagodovskaya and Lunin, 1997; Zhang et al., 2000; Li et al., 2004). After comparing the catalytic activity of the modified and unmodified $\mathrm{Ni} / \mathrm{Al}_{2} \mathrm{O}_{3}$ catalysts, the results showed that the ethanol conversion and $\mathrm{H}_{2}$ production of the modified catalyst were higher than the unmodified catalyst. The modified catalyst did not show any deactivation after $144 \mathrm{~h}$ of continuous use.

The effect of the preparation method and microstructural and compositional phase differences on the activity of $\mathrm{Ni} / \mathrm{Al}_{2} \mathrm{O}_{3}$ catalysts for the APR of methanol has been investigated (Roy et al., 2012a; $2012 b)$. An SCS- $\mathrm{Al}_{2} \mathrm{O}_{3}\left(\mathrm{Al}_{2} \mathrm{O}_{3}\right.$ support was made by a solution combustion synthesis route) sample with smaller Ni particles was found to be superior for methanol conversion, $\mathrm{H}_{2}$ selectivity, and $\mathrm{CO}_{2}$ production. The same phenomenon was observed on the $\mathrm{Ru} / \mathrm{TiO}_{2}$ catalyst in the APR of methanol (Nozawa et al., 2014).

3.2.3 Different supports of catalysts for non-noble catalysts

It has been observed that some types of basic supports, such as $\mathrm{MgO}, \mathrm{ZnO}$, can promote the hydrogen yield and the stability of catalysts in the APR process. Cruz et al. (2008) prepared a catalyst with
Ni loaded onto the derived hydrotalcite (NiHTC), and found that this catalyst showed higher activity in the APR process than a NiAl catalyst because of its larger surface area and pore volume. The XRD results showed that the lamellar structure of hydrotalcite-like compounds (HTLCs) disappeared and formed a poorly crystallized MgO-periclase phase after calcination. The dispersions of $\mathrm{Ni}$ and $\mathrm{Al}$ in the $\mathrm{MgO}$ matrix were good for the NiAl catalyst on a $\mathrm{MgO}$ support. Davidson et al. (2014) also reported that the $\mathrm{Co} / \mathrm{C}$ catalyst led to an effective cleavage of the $\mathrm{C}-\mathrm{C}$ bond, and the addition of $\mathrm{ZnO}$ provided more surface sites and enhanced the activation of $\mathrm{H}_{2} \mathrm{O}$.

\subsection{Aqueous-phase reforming of glycerol}

To solve the energy crisis in the world, biodiesel, which can be generated from vegetable oils, has become a substitute for petroleum. As the main by-product, the production of glycerol has increased rapidly and its subsequent utilization becomes more important (Pagliaro et al., 2007; Balat and Balat 2010; Huang et al., 2010; Wen et al., 2010). The APR of glycerol for hydrogen production is one attractive approach (Iriondo et al., 2008; Lehnert and Claus, 2008; Wen et al., 2008).

The mechanism of glycerol APR over Pt-based catalysts has been discussed (King et al., 2010; Wawrzetz et al., 2010; Zhang et al., 2012), and the possible reaction pathways are shown in Fig. 3. The differences of the pathways are dependent on the properties of the catalysts. The $\mathrm{Pt} / \mathrm{Al}_{2} \mathrm{O}_{3}$ catalyst possessed both metal and acid functions and enhanced glycerol dehydration to 3-hydroxypropanal. Moreover, Wawrzetz et al. (2010) proposed that the transformation of $\mathrm{Al}_{2} \mathrm{O}_{3}$ into boehmite supplied an acid-base site that promoted disproportionation in the reaction. The active phase of the Pt-Re/AC catalyst was Pt-Re alloy and $\mathrm{ReO}_{x}$. King et al. (2010) indicated that the Pt-Re alloy acted as a metalfunctionalized site resulting in $\mathrm{C}-\mathrm{C}$ bond cleavage, and $\mathrm{ReO}_{x}$ was intended to promote glyceraldehyde dehydration to produce pyruvaldehyde.

\subsubsection{Pt-based catalysts}

The catalyst $\mathrm{Pt} / \mathrm{Al}_{2} \mathrm{O}_{3}$ remains the most commonly applied catalyst in the APR of glycerol (Luo et al., 2008). Meryemoglu et al. (2012) used APR of 


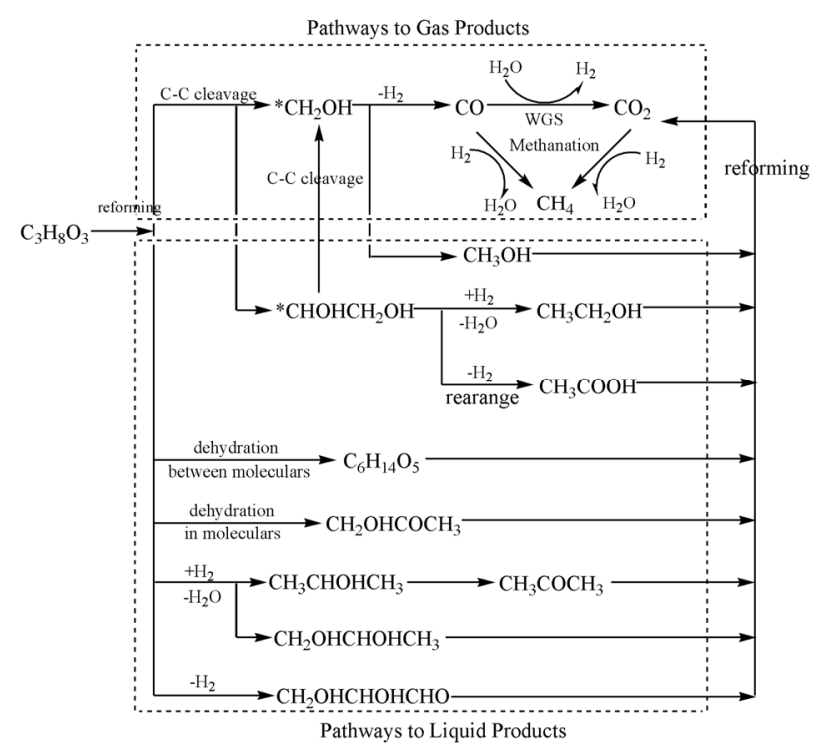

Fig. 3 Possible reaction network for the aqueous-phase reforming of glycerol (Reprinted from (Luo et al., 2008), Copyright 2008, with permission from Elsevier)

glycerol over $\mathrm{Pt} / \mathrm{Al}_{2} \mathrm{O}_{3}$ and $\mathrm{Pt} /$ carbon catalysts at $523 \mathrm{~K}$ and obtained lager gas volume. However, $\mathrm{Pt} / \mathrm{Al}_{2} \mathrm{O}_{3}$ produced less gas than a $\mathrm{Pt} /$ carbon catalyst at $573 \mathrm{~K}$. The effects of metal loadings and operation conditions to the APR process of glycerol for $\mathrm{H}_{2}$ production on $\mathrm{Pt} / \mathrm{Al}_{2} \mathrm{O}_{3}$ were investigated, and the results showed that a $0.9 \% \mathrm{Pt}$ loading possessed the highest activity for hydrogen generation. The optimal temperature was determined at $493 \mathrm{~K}$, which was similar to the $503 \mathrm{~K}$ temperature reported earlier (Özgür and Uysal, 2011). The amount of CO was expected to be as low as possible, but this would not always be achieved because of limitations of the reaction equipment. Thus, although $\mathrm{CO}_{2}$ concentration increased with increasing temperature, the WGS reaction could not go to completion.

The APR reaction is usually sensitive to particle size and the metal surface. Catalysts showed similar activity under the same reaction conditions, and no significant deactivation of the catalysts or formation of higher alkanes could be observed on Pt-based $\mathrm{Al}_{2} \mathrm{O}_{3}$ catalysts (Lehnert and Claus, 2008). In contrast, an increase in Pt particle size led to a decrease of the formation of $\mathrm{H}_{2}$ and $\mathrm{CO}_{2}$. This was identified with a decreasing concentration of metal sites, which favor the dehydration reactions (Wawrzetz et al., 2010). Barbelli et al. (2013) also observed the same experimental phenomenon on Pt-based catalysts. In addition, they suggested that small particle size would favor $\mathrm{C}-\mathrm{C}$ bond cleavage over $\mathrm{C}-\mathrm{O}$ bond cleavage and the hydrogenation reactions.

Doping of certain metals can improve the activity of catalysts. King et al. (2010) performed experiments for the APR of glycerol over $\mathrm{Pt} / \mathrm{C}$ and $\mathrm{Pt}-\mathrm{Re} / \mathrm{C}$ catalysts, and found that adding $\mathrm{Re}$ to $\mathrm{Pt}$ promoted the conversion of glycerol and $\mathrm{H}_{2}$ selectivity. It was suggested that Re might have a dual effect on Pt: first, the formation of the Pt-Re alloy led to an increased rate of dehydrogenation and decarbonylation; second, $\mathrm{ReO}_{x}$ led to liquid products and alkanes. Another explanation was that carbon-supported alloys of Pt with a Re catalyst were substantially more active in C-C bond cleavage than monometallic $\mathrm{Pt} /$ carbon catalysts. Further, such bimetallic catalysts increased WGS activity by rapidly removing CO from the surface (Ciftci et al., 2014). Dietrich et al. (2012) prepared a PtMo bimetallic nanoparticle catalyst for APR of glycerol. The result showed that the formation of this catalyst was Pt-rich in the core and Mo-rich at the surface. The PtMo nanoparticles increased slightly in size from 2 to $5 \mathrm{~nm}$ after $30 \mathrm{~d}$ of glycerol APR, and the structure can retain the Pt core-Mo shell morphology. The intermediates and products were related to both $\mathrm{C}-\mathrm{C}$ and $\mathrm{C}-\mathrm{OH}$ bond cleavage to give $\mathrm{H}_{2}, \mathrm{CO}_{2}$, and $\mathrm{CH}_{4}$. At low glycol conversion and high $\mathrm{H}_{2}$ selectivity, cleavage of the $\mathrm{C}-\mathrm{OH}$ bonds led to liquid products with saturated carbon atoms, whereas additional $\mathrm{CH}_{4}$ would be obtained and reduce the $\mathrm{H}_{2}$ yield and selectivity at high conversions. This was in contrast to $\mathrm{PtMo} /$ multi-walled carbon nanotube catalysts (Dietrich et al., 2014). In this case, Mo promoted the C-O cleavage and reduced the $\mathrm{H}_{2}$ yield at over $60 \%$ conversions. The difference could be on account of their different structures. Indeed, PtCo loaded onto the same support had a 4.6 times higher glycerol conversion than the Pt monometallic catalyst.

Nickel was sometimes utilized as a co-active component in Pt-based catalysts. The Pt-Ni $/ \gamma-\mathrm{Al}_{2} \mathrm{O}_{3}$ catalyst prepared by modified sol-gel preparation methods decreased the sintering effect on the Pt and Ni particles and avoided the formation of coke highly structured on the catalyst's surface (El Doukkali et al., 2012; 2014). He et al. (2015) indicated that $\mathrm{Pt}-\mathrm{Ni} /$ multi-walled carbon nanotube bimetallic catalysts improved the dehydrogenation-decarboxylation 
and dehydration-hydrogenation reactions, leading to the highest glycerol conversion rates observed to date $(81.21 \%)$.

\subsubsection{Ni-based catalysts}

Although the deactivations of Ni catalysts were observed in the APR process, $\mathrm{Ni}$ is still widely used as the main reactive species because of its low cost. However, several modifications to Ni catalysts have been reported in recent years to reduce such deactivations (Wen et al., 2008; King et al., 2010; Luo et al., 2010; Guo et al., 2012b).

Manfro et al. (2011) investigated the influence of the preparation method of Ni-based catalysts supported on $\mathrm{CeO}_{2}$ in the APR of glycerol (Table 4). The characterization showed that a lower specific surface area and better metal dispersion would be obtained for the catalyst prepared by combustion. Further, higher glycerol conversion and hydrogen production were also obtained when this method was used.

Guo et al. (2012b) used boron (B) to form a Ni-B alloy catalyst. The hydrogen production rate and hydrogen selectivity were higher than those on the Raney Ni catalyst because the doping of B would result in the formation of hexagonal closed-packed $\mathrm{Ni}$ crystallites and $\mathrm{B}_{2} \mathrm{O}_{3}$, which inhibit the sintering of $\mathrm{Ni}$ particles and impart better stability to the catalyst.

A Ni-Co bimetallic catalyst was prepared by urea matrix combustion. It was found that the $\mathrm{C}-\mathrm{C}$ bond cleavage ability was good because of $\mathrm{Ni}$ and an improvement of hydrogen selectivity was observed because of Co. Moreover, the addition of Co could suppress the sintering phenomenon, restrain methane selectivity, and improve the activity of the catalyst (Luo et al., 2010). Tuza et al. (2013) found that the addition of $\mathrm{Cu}$ decreased the formation of methane in the APR of glycerol, and also decreased the conversion of glycerol.

\subsubsection{Different supports for catalysts}

The supports also play an important role in the APR of glycerol. Pt- and Ni-based catalyst supports, such as $\mathrm{Al}_{2} \mathrm{O}_{3}, \mathrm{CeO}_{2}, \mathrm{MgO}$, and $\mathrm{SiO}_{2}$, were prepared to investigate the effect of supports on the activity of the catalysts for hydrogen production by APR of glycerol. The results are shown in Table 5 .

Menezes et al. (2011) prepared supported $\mathrm{Pt}$ catalysts using $\mathrm{Al}_{2} \mathrm{O}_{3}, \mathrm{CeO}_{2}, \mathrm{ZrO}_{2}$, and $\mathrm{MgO}$ as the carriers and tested their catalytic activity. In these $\mathrm{Pt}$ catalysts, $\mathrm{Al}_{2} \mathrm{O}_{3}$ and $\mathrm{ZrO}_{2}$ were amorphous, whereas $\mathrm{CeO}_{2}$ adopted a fluorite phase and $\mathrm{MgO}$ formed a periclase phase. The experimental results showed that all of the supports could result in an increase in the hydrogen production and a decrease in the concentration of undesired hydrocarbons, irrespective of the phase of the four supports.

Guo et al. (2012a) investigated the effect of the identity of the supports (i.e., $\mathrm{MgO}, \mathrm{Al}_{2} \mathrm{O}_{3}, \mathrm{CeO}_{2}$, $\mathrm{TiO}_{2}$, and $\mathrm{SiO}_{2}$ ) on the catalytic activity of the Ptbased catalyst in the APR process of glycerol. The catalytic activities of Pt-based catalysts decreased as $\mathrm{Pt} / \mathrm{MgO}>\mathrm{Pt} / \mathrm{Al}_{2} \mathrm{O}_{3}>\mathrm{Pt} / \mathrm{CeO}_{2}>\mathrm{Pt} / \mathrm{TiO}_{2}>\mathrm{Pt} / \mathrm{SiO}_{2}$. The WGS reactions played a key role in the APR process, which were enhanced by the acid-basic sites on the surface of the catalyst. Thus, the $\mathrm{Pt} / \mathrm{MgO}$ catalyst exhibited the best reaction activity. However, the trend reported by Wen et al (2008) was different as follows: $\quad \mathrm{Pt} / \mathrm{Al}_{2} \mathrm{O}_{3}>\mathrm{Pt} / \mathrm{MgO}>\mathrm{Pt} / \mathrm{SiO}_{2}>\mathrm{Pt} / \mathrm{HUSY}>$ $\mathrm{Pt} / \mathrm{AC}>\mathrm{Pt} / \mathrm{SAPO}-11$. A basic support resulted in high activity and hydrogen yield, whereas the acidic $\mathrm{Al}_{2} \mathrm{O}_{3}$ support and neutral support increased the formation of alkanes.

Table 4 Catalytic performance of different metal-doped Ni-based catalysts (Reprinted from (Manfro, 2011), Copyright 2011, with permission from Elsevier)

\begin{tabular}{cccccccr}
\hline Catalyst & $\begin{array}{c}\mathrm{NiO} \\
(\%)\end{array}$ & $\begin{array}{c}S_{\mathrm{BET}} \\
\left(\mathrm{m}^{2} / \mathrm{g}\right)\end{array}$ & $\begin{array}{c}V_{\text {pore }} \\
\left(\mathrm{m}^{3} / \mathrm{g}\right)\end{array}$ & $\begin{array}{c}\text { Reaction } \\
\text { temperature }(\mathrm{K})\end{array}$ & $\begin{array}{c}\text { Reaction } \\
\text { pressure }(\mathrm{MPa})\end{array}$ & $\begin{array}{c}\text { Conversion } \\
(\%)\end{array}$ & $\begin{array}{c}\mathrm{H}_{2} \\
\text { selectivity }(\%)\end{array}$ \\
\hline $\mathrm{NiCe}-\mathrm{Imp}^{\mathrm{a}}$ & 21.7 & 62 & 0.15 & 523 & 3.75 & 21.0 & 88.0 \\
${\mathrm{NiCe}-C p^{\mathrm{b}}}^{\mathrm{c}}$ & 20.6 & 51 & 0.20 & 523 & 3.75 & 16.0 & 122.2 \\
$\mathrm{NiCe}-C o m^{\mathrm{c}}$ & 19.6 & $<10$ & 0.01 & 523 & 3.75 & 12.0 & 186.8 \\
$\mathrm{NiCe}-\mathrm{Imp}$ & 21.7 & 62 & 0.15 & 543 & 5.27 & 18.8 & 71.4 \\
$\mathrm{NiCe}-\mathrm{Cp}$ & 20.6 & 51 & 0.20 & 543 & 5.27 & 17.5 & 82.4 \\
$\mathrm{NiCe}-\mathrm{Com}$ & 19.6 & $<10$ & 0.01 & 543 & 5.27 & 27.5 & 60.6 \\
\hline
\end{tabular}

\footnotetext{
${ }^{\mathrm{a}}$ Imp: wet impregnation; ${ }^{\mathrm{b}} \mathrm{Cp}$ : Co-precipitation; ${ }^{\mathrm{c}} \mathrm{Com}$ : combustion
} 
Iriondo et al. (2008) indicated that the structure and morphology of Ni catalysts could be modified by doping with $\mathrm{Zr}, \mathrm{Ce}, \mathrm{La}$, or $\mathrm{Mg}$. $\mathrm{Mg}$ modified the synergistic effect between $\mathrm{Ni}$ and $\mathrm{Al}_{2} \mathrm{O}_{3}$, and it enhanced the cooperation of $\mathrm{Ni}$ with the $\mathrm{Al}_{2} \mathrm{O}_{3}$ phase. The presence of $\mathrm{Zr}$ weakened the dispersion of $\mathrm{Ni}$ and displayed a strong $\mathrm{Ni}-\mathrm{ZrO}_{2}$ interaction. $\mathrm{Ce}$ and La partially covered the Ni phases. However, although the catalysts showed high activities at early reaction times, they deactivated quickly, which was ascribed to the change of $\mathrm{Ni}$ to an oxidized state with the formation of surface $\mathrm{NiAl}_{2} \mathrm{O}_{4}$.

\subsection{Aqueous-phase reforming of other alcohols}

Thus far, most feedstocks of APR processes for hydrogen production were alcohols derived from biomass, such as ethylene glycol and glycerol. However, studies of other alcohols in the APR process, such as methanol, butanol, sorbitol, mannitol, and xylitol, remain important branches of investigation.

Recently, $n$-butanol $(n$ - $\mathrm{BuOH})$ has been considered to be a potentially significant source of $\mathrm{H}_{2}$ because of its higher weight percent of $\mathrm{H}(13.5 \%)$ compared with ethanol (13.0\%) and methanol $(12.5 \%)$, low vapor pressure, flammability, and ease of handling. Additionally, $n$ - $\mathrm{BuOH}$ (or biobutanol) can be produced by fermenting sugar beets, sugar cane, corn, wheat, lignocellulosic biomass, and aqueous fractions of biomass pyrolysis liquids (i.e., bio-oil). Roy et al. (2011) studied the APR of $n$-BuOH over $\mathrm{Ni}(20 \%)$ loaded onto $\mathrm{Al}_{2} \mathrm{O}_{3}$ and $\mathrm{CeO}_{2}$ catalysts. The $\mathrm{Ni} / \mathrm{CeO}_{2}$ catalyst demonstrated higher selectivity for $\mathrm{H}_{2}$ and $\mathrm{CO}_{2}$, lower selectivity to alkanes, and a lower amount of $\mathrm{C}$ in the liquid phase compared with the $\mathrm{Ni} / \mathrm{Al}_{2} \mathrm{O}_{3}$ sample because of higher oxygen mobility in the $\mathrm{Ni}$ doped nonstoichiometric $\mathrm{CeO}_{2}$ lattice. For the $\mathrm{Ni} / \mathrm{CeO}_{2}$ and $\mathrm{Ni} / \mathrm{Al}_{2} \mathrm{O}_{3}$ catalysts, the highest $n-\mathrm{BuOH}$ conversion was $5.77 \%$ and $2.76 \%$ on the $\mathrm{Ni} / \mathrm{CeO}_{2}$ and $\mathrm{Ni} / \mathrm{Al}_{2} \mathrm{O}_{3}$ catalysts at $488 \mathrm{~K}$, respectively. The low conversion led to a few subsequent investigations.

Sorbitol as a starting material for the APR process has attracted considerable interest because of its relatively large number of successive $\mathrm{C}-\mathrm{C}$ and $\mathrm{C}-\mathrm{O}$ bonds (Cortright et al., 2002; Huber et al., 2003; Tanksale et al., 2008). Li and Huber (2010)

Table 5 Effect of the support for different catalysts on the APR process

\begin{tabular}{|c|c|c|c|c|c|c|c|c|}
\hline Catalyst & $\begin{array}{c}\text { Pt loading } \\
(\%)\end{array}$ & $\begin{array}{c}S_{\mathrm{BET}} \\
\left(\mathrm{m}^{2} / \mathrm{g}\right)\end{array}$ & $\begin{array}{l}\text { Total pore } \\
\text { volume } \\
\left(\mathrm{cm}^{3} / \mathrm{g}\right)\end{array}$ & $\begin{array}{l}\text { Average pore } \\
\text { size }(\mathrm{nm})\end{array}$ & $\begin{array}{c}\text { Conversion } \\
(\%)\end{array}$ & $\begin{array}{c}\mathrm{H}_{2} \text { selectivity } \\
(\%)\end{array}$ & $\begin{array}{c}\text { Yield rate of } \mathrm{H}_{2} \\
\text { production } \\
\left(\mu \mathrm{mol} /\left(\mathrm{g}_{\text {cat }} \cdot \mathrm{min}\right)\right)\end{array}$ & Reference \\
\hline $\mathrm{Pt} / \mathrm{Al}_{2} \mathrm{O}_{3}$ & 1.22 & - & - & - & 23 & 49.3 & - & \multirow{4}{*}{$\begin{array}{c}\text { Menezes et } \\
a l ., 2011^{\mathrm{a}}\end{array}$} \\
\hline $\mathrm{Pt} / \mathrm{CeO}_{2}$ & 1.49 & - & - & - & 13 & 52.5 & - & \\
\hline $\mathrm{Pt} / \mathrm{ZrO}_{2}$ & 1.13 & - & - & - & 26 & 46.1 & - & \\
\hline $\mathrm{Pt} / \mathrm{MgO}$ & 1.44 & - & - & - & 20 & 73.3 & - & \\
\hline $\mathrm{Pt} / \mathrm{MgO}$ & 0.79 & 42 & 0.20 & 3.82 & 48 & 60 & - & \multirow{5}{*}{$\begin{array}{c}\text { Guo et al., } \\
2012 \mathrm{a}^{\mathrm{b}}\end{array}$} \\
\hline $\mathrm{Pt} / \mathrm{Al}_{2} \mathrm{O}_{3}$ & 0.74 & 228 & 0.34 & 3.43 & 38 & 66 & - & \\
\hline $\mathrm{Pt} / \mathrm{CeO}_{2}$ & 0.75 & 58 & 0.01 & 3.82 & 35 & 61 & - & \\
\hline $\mathrm{Pt} / \mathrm{TiO}_{2}$ & 0.72 & 35 & 0.18 & 5.46 & 27 & 56 & - & \\
\hline $\mathrm{Pt} / \mathrm{SiO}_{2}$ & 0.76 & 259 & 0.70 & 5.51 & 20 & 70 & - & \\
\hline $\mathrm{Pt} / \mathrm{Al}_{2} \mathrm{O}_{3}$ & 4.38 & 229.0 & 0.663 & 9.6 & 18.9 & 65.7 & 572.2 & \multirow{6}{*}{$\begin{array}{l}\text { Wen et al., } \\
2008^{\mathrm{c}}\end{array}$} \\
\hline $\mathrm{Pt} / \mathrm{SiO}_{2}$ & 4.34 & 105.2 & 0.400 & 6.6 & 10.8 & 72.8 & 369.4 & \\
\hline $\mathrm{Pt} / \mathrm{AC}$ & 4.23 & 721.3 & 0.098 & 3.8 & 17.2 & 65.7 & 307.7 & \\
\hline $\mathrm{Pt} / \mathrm{MgO}$ & 9.84 & 302.9 & 0.732 & 5.6 & 13.8 & 113.0 & 431.9 & \\
\hline $\mathrm{Pt} / \mathrm{HUSY}$ & 5.10 & 436.8 & 0.133 & 3.8 & 22.0 & 72.6 & 337.0 & \\
\hline Pt/MSAPO-11 & 5.31 & 137.1 & 0.124 & 2.8 & 13.3 & 76.8 & 222.1 & \\
\hline $\mathrm{Ni} / \mathrm{Al}_{2} \mathrm{O}_{3}$ & 14.5 & 207 & 0.77 & 14.8 & 25 & - & - & \multirow{5}{*}{$\begin{array}{l}\text { Iriondo et } \\
\text { al., } 2008^{\mathrm{d}}\end{array}$} \\
\hline $\mathrm{Ni} / \mathrm{Al}_{2} \mathrm{O}_{3}-\mathrm{ZrO}_{2}$ & 15.4 & 229 & 0.81 & 14.0 & 30 & 13.4 & - & \\
\hline $\mathrm{Ni} / \mathrm{Al}_{2} \mathrm{O}_{3}-\mathrm{CeO}_{2}$ & 14.5 & 215 & 0.81 & 14.3 & 36 & 13.4 & - & \\
\hline $\mathrm{Ni} / \mathrm{Al}_{2} \mathrm{O}_{3}-\mathrm{MgO}$ & 14.5 & 218 & 0.82 & 14.1 & 15 & 26.4 & - & \\
\hline $\mathrm{Ni} / \mathrm{Al}_{2} \mathrm{O}_{3}-\mathrm{La}_{2} \mathrm{O}_{3}$ & 15.4 & 225 & 0.81 & 14.3 & 37 & 13.4 & - & \\
\hline
\end{tabular}

Reaction conditions: ${ }^{\text {a }} 10 \%$ glycerol, $503 \mathrm{~K}, 3.2 \mathrm{MPa} ;{ }^{\text {b }} 1 \%$ glycerol, $498 \mathrm{~K}$, autogenous pressure; ${ }^{\text {c }} 5 \%$ glycerol, $498 \mathrm{~K}, 2.76 \mathrm{MPa}$; d $1 \%$ glycerol, $498 \mathrm{~K}, 3.0 \mathrm{MPa}$ 
proposed that a closed-loop dehydration of sorbitol into $\mathrm{C}_{6}$ was the first reaction to occur on acidic centers, and cleavage of the C-C bond of sorbitol into $\mathrm{C}_{3}$ fragments was easier on the Pt-based catalysts. Tanksale et al. (2008) combined small quantities of Pt or Pd with a Ni catalyst to prepare the alloy catalysts for the APR process of sorbitol. The results showed that the hydrogen formation rate for the alloy catalysts were 3-5 times higher than that measured for the monometallic Ni catalysts. The results were rationalized as follows: first, the increase of reduction of Ni led to a higher number of active sites; second, the alloying of $\mathrm{Pt} / \mathrm{Ni}$ decreased the $\mathrm{C}-\mathrm{O}$ binding energy on the active metal. In other words, poisoning the catalyst was inhibited and the available number of active sites was increased. Aiouache et al. (2013) added $\mathrm{Pd}$ to the $\mathrm{Ni} / \gamma-\mathrm{Al}_{2} \mathrm{O}_{3}$ catalyst and found that the nickel dispersion and reducibility were increased, made the $\mathrm{H}_{2}$ production higher, and led to a lower $\mathrm{CO}_{2}$ production. The introduction of a small amount of $\mathrm{Pd}$ appeared to inhibit the remaining reactions via surface carbon intermediates that were tightly bound to the surface of the catalyst. In (Tanksale et al., 2009)'s investigation, different supports (i.e., alumina nano-fibre (Alnf), $\mathrm{ZrO}_{2}$, and mixed oxides of ceria-zirconia-silica $\left(\mathrm{CZ}_{x} \mathrm{~S}\right)$ ) were chosen to prepare bimetallic Pt-Ni catalysts for the APR of sorbitol. It was observed that the rate of $\mathrm{H}_{2}$ production for the co-impregnated $\mathrm{Ni} / \mathrm{Pt}$ catalysts was higher than the sequentially impregnated $\mathrm{Pt} / \mathrm{Ni}$ catalysts and monometallic Ni catalysts. Silica did not form any compound with ceria-zirconia but instead existed as an amorphous layer on the $\mathrm{Ce}_{x} \mathrm{Zr}_{1-x} \mathrm{O}_{2}$ crystals. The hydrogen activity decreased in the following order of the supports: $A \ln f>$ $\mathrm{ZrO}_{2}>\mathrm{CZ} 3 \mathrm{~S}>\mathrm{CZ7S}$.

Although xylitol is the second most abundant sugar alcohol, which is produced by the catalytic hydrogenation of xylose monomers generated from hemicelluloses, it has attracted very little attention (Sjöström. 1993). A Pt/ $\mathrm{Al}_{2} \mathrm{O}_{3}$ catalyst presented good stability (only $10 \%$ decreased after $120 \mathrm{~h}$ timeon-stream) in the APR of xylitol, and could be improved by regeneration. No deactivation was observed on $\mathrm{Pt} / \mathrm{TiO}_{2}$ (Kirilin et al., 2012). In the following study, Kirilin et al. (2014) found that the addition of $\mathrm{Re}$ to the $\mathrm{Pt} / \mathrm{TiO}_{2}$ catalyst decreased the number of surface acid sites, and this could result in the formation of hydrocarbons. Kim et al. (2014) proposed that the pore structure of the support played a more critical role in the APR of xylitol. Three-dimensionally mesoporous carbon with larger secondary mesopore Pt supported catalysts was more favorable for the production of $\mathrm{H}_{2}$ because of its unique mesoporous structure. $\mathrm{H}_{2}$ selectivity was higher and alkane selectivity was lower for glycerol than for xylitol. Because xylitol has a longer carbon chain than glycerol, it is likely that the frequency of some side reactions, such as methanation/FischerTropsch synthesis, would increase and consume the hydrogen previously generated. This conclusion is relevant for the other alcohols as well. Indeed, higher $\mathrm{H}_{2}$ yields and $\mathrm{H}_{2}$ selectivities were observed in the APR of xylitol compared with sorbitol, which has a longer carbon chain (Kirilin et al., 2012).

\subsection{A comparison of reaction mechanisms for different types of alcohols}

As the simplest model of alcohols, early studies of hydrogen generation through the APR reaction mainly focused on ethylene glycol. The catalytic performance of ethanol appeared to be an excellent strategy to obtain hydrogen by the steam reforming reaction, and some scholars attempted to utilize ethanol in the APR reaction as a raw material and obtained high production efficiency. In recent years, because of the rapid development of biodiesel technology, the transformation of its main by-product (i.e., glycerol) has prompted a considerable number of investigations. For other alcohols that have more complicated structures, such as sorbitol and xylitol, studies on the APR reaction have only just begun. Although it is not a direct derivative of biomass, methanol was often chosen as a reference material to investigate the $\mathrm{C}-\mathrm{C}$ bond cleavage efficiency for different catalysts because no $\mathrm{C}-\mathrm{C}$ bond cleavage would occur during the APR process. To investigate the differences between the alcohols discussed above in the APR reactions for hydrogen production, some investigators performed parallel investigations.

Shabaker et al. (2003) measured the reaction rates of the APR process of methanol and ethylene glycol for $\mathrm{H}_{2}$ and $\mathrm{CO}_{2}$ production under kinetic control on $\mathrm{Pt} / \mathrm{Al}_{2} \mathrm{O}_{3}$ catalysts. The similar results for methanol and ethylene glycol suggested that the C-C bond cleavage was not the decisive step in the APR 
process. The $\mathrm{H}_{2}$ production rate for methanol was higher than ethylene glycol because the reaction involving the former would be weakly inhibited by the surface active sites occupied by hydrogen atoms and other intermediate species derived from ethylene glycol.

Liu (2011) prepared five different types of catalysts (i.e., $\mathrm{Pt} / \gamma-\mathrm{Al}_{2} \mathrm{O}_{3}, \mathrm{Pt} / \delta-\mathrm{Al}_{2} \mathrm{O}_{3}, \mathrm{Pt} / \alpha-\mathrm{Al}_{2} \mathrm{O}_{3}, \mathrm{Pt} / \alpha-$ $\mathrm{Fe}_{2} \mathrm{O}_{3}$, and $\mathrm{Pt} / \mathrm{CeO}_{2}$ ) for the APR process involving methanol and ethylene glycol. The results from these reactions are shown in Table 6 . The conversion of ethylene glycol was higher than that of methanol, suggesting that the effect of the C-C bond cleavage on the catalysts was not clear. In addition, both the conversion and $\mathrm{H}_{2}$ selectivity for ethylene glycol were higher than they were for methanol, which demonstrated that the reforming of ethylene glycol on the supported catalysts was not only a simple C-C bond cleavage combined with the methanol APR reaction but also the reaction mechanism of the reforming of methanol and ethylene glycol were completely different. The conclusion that $\mathrm{C}-\mathrm{C}$ bond cleavage was not the decisive step in the APR process was demonstrated once again.

Cortright et al. (2002) found that the hydrogen concentration and selectivity from methanol achieved the highest level among some alcohols (Table 7). The hydrogen selectivity of these alcohols increased in the order: sorbitol<glycerol<ethylene glycol $<$ methanol. However, $\mathrm{CO}_{2}$ formation and hydrocarbon conversion followed the opposite order: methanol<ethylene glycol<glycerol<sorbitol. This observation can be related to the number of carbon atoms of the alcohols. With an increase in the number of carbons, the by-reactions decreased and condensation of the alcohols became easier, which results in the reduction of hydrogen production and the promotion of the formation of $\mathrm{CO}_{2}$ and hydrocarbon compounds. This theory is consistent with the results reported by Tang et al. (2009) and Wen et al. (2009).

Table 6 Catalytic activity for the APR of methanol/ethylene glycol on supported catalysts (Liu, 2011)

\begin{tabular}{ccccccc}
\hline \multirow{2}{*}{ Catalyst } & \multirow{2}{*}{ Feedstock } & Conversion & \multicolumn{3}{c}{ Rate of production $\left(\mu \mathrm{mol} /\left(\mathrm{g}_{\text {cat }} \cdot \min \right)\right)$} \\
\cline { 3 - 7 } & & $(\%)$ & $\mathrm{H}_{2}$ & $\mathrm{CO}$ & $\mathrm{CH}_{4}$ & $\mathrm{CO}_{2}$ \\
\hline $\mathrm{Pt} / \gamma-\mathrm{Al}_{2} \mathrm{O}_{3}$ & Methanol & 13.1 & 197 & 0.017 & 0.97 & 62.3 \\
$\mathrm{Pt} / \gamma-\mathrm{Al}_{2} \mathrm{O}_{3}$ & Ethylene glycol & 15.2 & 218 & 0.30 & 1.42 & 90.3 \\
$\mathrm{Pt} / \delta-\mathrm{Al}_{2} \mathrm{O}_{3}$ & Methanol & 13.8 & 164 & 0.01 & 1.01 & 28.6 \\
$\mathrm{Pt} / \delta-\mathrm{Al}_{2} \mathrm{O}_{3}$ & Ethylene glycol & 20.9 & 321 & 0.42 & 1.87 & 106.7 \\
$\mathrm{Pt} / \alpha-\mathrm{Al}_{2} \mathrm{O}_{3}$ & Methanol & 10.5 & 145 & 0.01 & 1.10 & 40.8 \\
$\mathrm{Pt} / \alpha-\mathrm{Al}_{2} \mathrm{O}_{3}$ & Ethylene glycol & 18.1 & 452 & 0.50 & 1.95 & 77.9 \\
$\mathrm{Pt} / \alpha-\mathrm{Fe}_{2} \mathrm{O}_{3}$ & Methanol & 4.5 & 24 & 0.007 & 0.02 & 17.9 \\
$\mathrm{Pt} / \alpha-\mathrm{Fe}_{2} \mathrm{O}_{3}$ & Ethylene glycol & 13.8 & 116 & 0.11 & 0.21 & 48.1 \\
$\mathrm{Pt} / \mathrm{CeO}_{2}$ & Methanol & 3.8 & 41 & 0.03 & 0.20 & 20.1 \\
$\mathrm{Pt} / \mathrm{CeO}_{2}$ & Ethylene glycol & 6.1 & 85 & 0.58 & 0.62 & 38.8 \\
\hline
\end{tabular}

Table 7 APR reaction data for different alcohols (Reprinted from (Cortright et al., 2002), Copyright 2002, with permission from Nature)

\begin{tabular}{|c|c|c|c|c|c|c|c|c|c|c|}
\hline \multirow[t]{2}{*}{ Feedstock } & \multirow{2}{*}{$\begin{array}{l}\text { Concentra- } \\
\text { tion }(\%)\end{array}$} & \multirow[t]{2}{*}{$\begin{array}{c}\text { - Tempera- } \\
\text { ture }(\mathrm{K})\end{array}$} & \multirow{2}{*}{$\begin{array}{l}\text { Pressure } \\
(\mathrm{MPa})\end{array}$} & \multirow{2}{*}{$\begin{array}{l}\text { Carbon in } \\
\text { liquid-phase } \\
\text { effluent (\%) }\end{array}$} & \multirow{2}{*}{$\begin{array}{l}\text { Carbon in } \\
\text { gas-phase } \\
\text { effluent (\%) }\end{array}$} & \multicolumn{3}{|c|}{$\begin{array}{c}\text { Gas-phase } \\
\text { composition (\%) }\end{array}$} & \multirow{2}{*}{$\begin{array}{c}\mathrm{H}_{2} \\
\text { selectivity } \\
(\%)\end{array}$} & \multirow{2}{*}{$\begin{array}{c}\text { Alkane } \\
\text { selectivity }(\%)\end{array}$} \\
\hline & & & & & & $\mathrm{H}_{2}$ & $\mathrm{CO}_{2}$ & $\mathrm{CH}_{4}$ & & \\
\hline \multirow[t]{2}{*}{ Methanol } & 12.5 & 498 & 2.9 & 6.5 & 94 & 74.6 & 25 & 0.0 & 99 & 1.7 \\
\hline & & 538 & 5.6 & 6.4 & 94 & 74.8 & 24.6 & 0.0 & 99 & 2.7 \\
\hline \multirow{2}{*}{$\begin{array}{l}\text { Ethylene } \\
\text { glycol }\end{array}$} & 9.7 & 498 & 2.9 & 11 & 90 & 70 & 29.1 & 0.1 & 96 & 4 \\
\hline & & 538 & 5.6 & 2.9 & 99 & 68.7 & 29 & 0.3 & 88 & 8 \\
\hline \multirow[t]{2}{*}{ Glycerol } & 8.6 & 498 & 2.9 & 17 & 83 & 64.8 & 29.7 & 0.9 & 75 & 19 \\
\hline & & 538 & 5.6 & 2.8 & 99 & 57 & 32 & 2.0 & 51 & 31 \\
\hline \multirow[t]{2}{*}{ Sorbitol } & 7.6 & 498 & 2.9 & 29 & 61 & 61 & 35 & 2.3 & 66 & 15 \\
\hline & & 538 & 5.6 & 12 & 90 & 54 & 36 & 0.7 & 46 & 32 \\
\hline
\end{tabular}




\section{Conclusions}

The APR of biomass-derived alcohols for hydrogen production has been considered a promising approach because of its wide renewable resource, mild reaction conditions, and low processing cost. In this process, increasing attention is focused toward ethylene glycol, and glycerol rather than other alcohols, such as methanol, ethanol, sorbitol, and xylitol.

The APR of ethylene glycol and ethanol on Ptbased catalysts presented high conversion but low $\mathrm{H}_{2}$ yield, and little research on non-noble metal catalysts was performed. For the complex structure of glycerol, the major studies focused on bimetallic catalysts to improve $\mathrm{H}_{2}$ selectivity and conversion. However, the $\mathrm{H}_{2}$ yield on the noble metal catalysts remained low. The conversions of $n$-butanol on the $\mathrm{Ni} / \mathrm{CeO}_{2}$ and $\mathrm{Ni} / \mathrm{Al}_{2} \mathrm{O}_{3}$ catalysts were rather low, at approximately $5.77 \%$ and $2.76 \%$, respectively, whereas the $\mathrm{H}_{2}$ selectivity was high. For APR of other alcohols, $99 \% \mathrm{H}_{2}$ selectivity was obtained by small molecule polyols. Degradation and condensation took place with an increase in molecular weight of the alcohols, resulting in a decline in $\mathrm{H}_{2}$ selectivity from $99 \%$ to $46 \%$ and a rise in alkane formation from $1.7 \%$ to $32 \%$.

In the APR reaction of alcohols, the main catalysts are noble-metal catalysts and nickel catalysts. Noble-metal catalysts, including $\mathrm{Pt}, \mathrm{Pd}, \mathrm{Ru}$, and Ir, show high selectivity in $\mathrm{H}_{2}$ production but the conversion of alcohols is low. Ni-based catalysts show high conversion of alcohols but low $\mathrm{H}_{2}$ selectivity and yields. The addition of $\mathrm{Re}, \mathrm{Ce}, \mathrm{Mg}, \mathrm{Mo}$, and $\mathrm{Co}$ to Pt-based catalysts can improve the conversion of alcohols to varying degrees, but the $\mathrm{H}_{2}$ selectivity and yield decreased for the PtMo catalyst. The $\mathrm{H}_{2}$ selectivity would be enhanced with $\mathrm{Pt}, \mathrm{Sn}, \mathrm{Ce}, \mathrm{B}$, and $\mathrm{Co}$ on Ni-based catalysts, whereas the conversion of alcohols would reduce on $\mathrm{NiCu}$ catalyst. If an appropriate support could improve the dispersion of metal and increase the utilization rate of the active sites, then the activity and stability would also be influenced.

At present, the APR process to convert biomass into hydrogen is only at the research and development stage. Future work should focus on developing catalysts of high efficiency, stability, and low cost. Moreover, movement away from micro reactors to new reactor designs that can rapidly separate products but can accommodate larger volumes and concentrations of reactants should be pursued.

\section{References}

Aiouache, F., McAleer, L., Gan Q., et al., 2013. Path lumping kinetic model for aqueous phase reforming of sorbitol. Applied Catalysis A: General, 466:240-255. [doi:10. 1016/j.apcata.2013.06.039]

Bai, Y., Lu, C.S., Ma, L., et al., 2006. Hydrogen production by aqueous-phase reforming of ethylene glycol over $\mathrm{Pt}$ catalysts supported on $\gamma-\mathrm{Al}_{2} \mathrm{O}_{3}$ modified with $\mathrm{Ce}$ and $\mathrm{Mg}$. Chinese Journal of Catalysis, 27(3):275-280 (in Chinese).

Balat, M., Balat, H., 2010. Progress in biodiesel processing. Applied Energy, 87(6):1815-1835. [doi:10.1016/j. apenergy.2010.01.012]

Barbelli, M.L., Pompeo, F., Santori, G.F., et al., 2013. Pt catalyst supported on $\alpha-\mathrm{Al}_{2} \mathrm{O}_{3}$ modified with $\mathrm{CeO}_{2}$ and $\mathrm{ZrO}_{2}$ for aqueous-phase-reforming of glycerol. Catalysis Today, 213:58-64. [doi:10.1016/j.cattod.2013.02.023]

Chu, X.W., Liu, J., Qiao, M.H., et al., 2009. Aqueous-phase reforming of ethylene glycol to $\mathrm{H}_{2}$ on Sn-modified rapidly quenched skeletal Ni-Mo catalyst. Chinese Journal of Catalysis, 30(7):595-600 (in Chinese).

Chu, X.W., Liu, J., Sun, B., et al., 2011. Aqueous-phase reforming of ethylene glycol on $\mathrm{Co} / \mathrm{ZnO}$ catalysts prepared by the coprecipitation method. Journal of Molecular Catalysis A: Chemical, 335:129-135. [doi:10. 1016/j.molcata.2010.11.024]

Ciftci, A., Ligthart, D., Sen, A., et al., 2014. Pt-Re synergy in aqueous-phase reforming of glycerol and the water-gas shift reaction. Journal of Catalysis, 311:88-101. [doi:10. 1016/j.jcat.2013.11.011]

Cortright, R., Davda, R., Dumesic, J., 2002. Hydrogen from catalytic reforming of biomass-derived hydrocarbons in liquid water. Nature, 418(6901):964-976. [doi:10.1038/ nature01009]

Cruz, I.O., Ribeiro, N.F., Aranda, D.A., et al., 2008. Hydrogen production by aqueous-phase reforming of ethanol over nickel catalysts prepared from hydrotalcite precursors. Catalysis Communications, 9(15):2606-2611. [doi:10.1016/j.catcom.2008.07.031]

Dadashova, E., Yagodovskaya, T., Beilin, L., et al., 1991. Modification of $\mathrm{Fe}_{2} \mathrm{O}_{3} / \mathrm{ZSM}$ catalyst of Fischer-Tropsch synthesis by glow discharge in oxygen and in argon. Kinetics and Catalysis, 32(6):1350-1352.

Dadashova, E., Yagodovskaya, T., Shpiro, E., et al., 1993. The synthesis of $\mathrm{Fe}_{2} \mathrm{O}_{3} / \mathrm{ZSM}-5$ catalyst for carbon monoxide hydrogenation in glow discharge of oxygen and argon. Kinetics and Catalysis, 34(4):670-673.

Davda, R., Shabaker, J., Huber, G., et al., 2003. Aqueousphase reforming of ethylene glycol on silica-supported metal catalysts. Applied Catalysis B: Environmental, 43(1):13-26. [doi:10.1016/S0926-3373(02)00277-1] 
Davda, R., Shabaker, J., Huber, G., et al., 2005. A review of catalytic issues and process conditions for renewable hydrogen and alkanes by aqueous-phase reforming of oxygenated hydrocarbons over supported metal catalysts. Applied Catalysis B: Environmental, 56:171-186. [doi:10.1016/j.apcatb.2004.04.027]

Davidson, S.D., Sun, J., Hong, Y., et al., 2014. The effect of $\mathrm{ZnO}$ addition on $\mathrm{Co} / \mathrm{C}$ catalyst for vapor and aqueous phase reforming of ethanol. Catalysis Today, 233:38-45. [doi:10.1016/j.cattod.2013.12.044]

de Vlieger, D.J.M., Mojet, B.L., Lefferts, L., et al., 2012. Aqueous phase reforming of ethylene glycol-role of intermediates in catalyst performance. Journal of Catalysis, 292:239-245. [doi:10.1016/j.jcat.2012.05.019]

Dietrich, P.J., Lobo-Lapidus, R.J., Wu, T., et al., 2012. Aqueous phase glycerol reforming by PtMo bimetallic nano-particle catalyst: product selectivity and structural characterization. Topics in Catalysis, 55(1-2):53-69. [doi:10.1007/s11244-012-9775-5]

Dietrich, P.J., Sollberger, F.G., Akatay, M.C., et al., 2014. Structural and catalytic differences in the effect of $\mathrm{Co}$ and Mo as promoters for Pt-based aqueous phase reforming catalysts. Applied Catalysis B: Environmental, 156-157:236-248. [doi:10.1016/j.apcatb.2014.03.016]

Dixit, R.S., Tavlarides, L.L., 1983. Kinetics of the FischerTropsch synthesis. Industrial \& Engineering Chemistry Process Design and Development, 22(1):1-9. [doi:10. 1021/i200020a001]

El Doukkali, M., Iriondo, A., Arias, P., et al., 2012. A comparison of sol-gel and impregnated $\mathrm{Pt}$ or/and $\mathrm{Ni}$ based $\gamma$-alumina catalysts for bioglycerol aqueous phase reforming. Applied Catalysis B: Environmental, 125: 516-529. [doi:10.1016/j.apcatb.2012.06.024]

El Doukkali, M., Iriondo, A., Cambra, J., et al., 2014. Recent improvement on $\mathrm{H}_{2}$ production by liquid phase reforming of glycerol: catalytic properties and performance, and deactivation studies. Topics in Catalysis, 57(10-13): 1066-1077. [doi:10.1007/s11244-014-0271-y]

Guo, Y., Azmat, M.U., Liu, X., et al., 2012a. Effect of support's basic properties on hydrogen production in aqueous-phase reforming of glycerol and correlation between WGS and APR. Applied Energy, 92:218-223. [doi:10.1016/j.apenergy.2011.10.020]

Guo, Y., Liu, X., Azmat, M.U., et al., 2012b. Hydrogen production by aqueous-phase reforming of glycerol over $\mathrm{Ni}-\mathrm{B}$ catalysts. International Journal of Hydrogen Energy, 37(1):227-234. [doi:10.1016/j.ijhydene.2011.09. 111]

He, C., Zheng, J.W., Wang, K., et al., 2015. Sorption enhanced aqueous phase reforming of glycerol for hydrogen production over Pt-Ni supported on multiwalled carbon nanotubes. Applied Catalysis B: Environmental, 162:401-411. [doi:10.1016/j.apcatb.2014. 07.012]

Huang, G., Chen, F., Wei, D., et al., 2010. Biodiesel production by microalgal biotechnology. Applied Energy, 87(1):38-46. [doi:10.1016/j.apenergy.2009.06.016]
Huber, G.W., Shabaker, J., Dumesic, J., 2003. Raney Ni-Sn catalyst for $\mathrm{H}_{2}$ production from biomass-derived hydrocarbons. Science, 300(5628):2075-2077. [doi:10. 1126/science.1085597]

Huber, G.W., Cortright, R.D., Dumesic, J.A., 2004. Renewable alkanes by aqueous-phase reforming of biomass-derived oxygenates. Angewandte Chemie International Edition, 43(12):1549-1551. [doi:10.1002/ anie.200353050]

Huber, G.W., Shabaker, J.W., Evans, S.T., et al., 2006. Aqueous-phase reforming of ethylene glycol over supported $\mathrm{Pt}$ and $\mathrm{Pd}$ bimetallic catalysts. Applied Catalysis B: Environmental, 62:226-235. [doi:10.1016/ j.apcatb.2005.07.010]

Iglesia, E., Soled, S.L., Fiato, R.A., 1992. Fischer-Tropsch synthesis on cobalt and ruthenium. Metal dispersion and support effects on reaction rate and selectivity. Journal of Catalysis, 137(1):212-224. [doi:10.1016/0021-9517 (92) $90150-\mathrm{G}]$

Iriondo, A., Barrio, V., Cambra, J., et al., 2008. Hydrogen production from glycerol over nickel catalysts supported on $\mathrm{Al}_{2} \mathrm{O}_{3}$ modified by $\mathrm{Mg}, \mathrm{Zr}, \mathrm{Ce}$ or La. Topics in Catalysis, 49(1-2):46-58. [doi:10.1007/s11244-0089060-9]

Jeong, K.E., Kim, H.D., Kim, T.W., et al., 2014. Hydrogen production by aqueous phase reforming of polyols over nano- and micro-sized mesoporous carbon supported platinum catalysts. Catalysis Today, 232:151-157. [doi:10.1016/j.cattod.2014.02.005]

Kellner, C.S., Bell, A.T., 1981. The kinetics and mechanism of carbon monoxide hydrogenation over aluminasupported ruthenium. Journal of Catalysis, 70(2):418432. [doi:10.1016/0021-9517(81)90354-7]

Kim, H.D., Park, H.J., Kim, T.W., et al., 2012a. Hydrogen production through the aqueous phase reforming of ethylene glycol over supported Pt-based bimetallic catalysts. International Journal of Hydrogen Energy, 37(10):8310-8317. [doi:10.1016/j.ijhydene.2012.02.160]

Kim, H.D., Kim, T.W., Park, H.J., et al., 2012b. Hydrogen production via the aqueous phase reforming of ethylene glycol over platinum-supported ordered mesoporous carbon catalysts: effect of structure and frameworkconfiguration. International Journal of Hydrogen Energy, 37(17):12187-12197. [doi:10.1016/j.ijhydene. 2012.05.126]

Kim, H.D., Park, H.J., Kim, T.W., et al., 2012c. The effect of support and reaction conditions on aqueous phase reforming of polyol over supported Pt-Re bimetallic catalysts. Catalysis Today, 185(1):73-80. [doi:10.1016/j. cattod.2011.08.012]

Kim, T.W., Kim, H.D., Jeong, K.E., et al., 2011. Catalytic production of hydrogen through aqueous-phase reforming over platinum/ordered mesoporous carbon catalysts. Green Chemistry, 13(7):1718-1728. [doi:10. 1039/c1gc15235a]

Kim, T.W., Park, H.J., Yang, Y.C., et al., 2014. Hydrogen production via the aqueous phase reforming of polyols 
over three dimensionally mesoporous carbon supported catalysts. International Journal of Hydrogen Energy, 39(22):11509-11516. [doi:10.1016/j.ijhydene.2014.05. 106]

King, D.L., Zhang, L., Xia, G., et al., 2010. Aqueous phase reforming of glycerol for hydrogen production over PtRe supported on carbon. Applied Catalysis B: Environmental, 99:206-213. [doi:10.1016/j.apcatb.2010. 06.021]

Kirilin, A.V., Tokarev, A.V., Kustov, L.M., et al., 2012. Aqueous phase reforming of xylitol and sorbitol: comparison and influence of substrate structure. Applied Catalysis A: General, 435-436:172-180. [doi:10.1016/j. apcata.2012.05.050]

Kirilin, A.V., Tokarev, A.V., Manyar, H., et al., 2014. Aqueous phase reforming of xylitol over Pt-Re bimetallic catalyst: effect of the Re addition. Catalysis Today, 223:97-107. [doi:10. 1016/j.cattod.2013.09.020]

Lehnert, K., Claus, P., 2008. Influence of Pt particle size and support type on the aqueous-phase reforming of glycerol. Catalysis Communications, 9(15):2543-2546. [doi:10. 1016/j.catcom.2008.07.002]

Li, N., Huber, G.W., 2010. Aqueous-phase hydrodeoxygenation of sorbitol with $\mathrm{Pt} / \mathrm{SiO}_{2}-\mathrm{Al}_{2} \mathrm{O}_{3}$ : identification of reaction intermediates. Journal of Catalysis, 270(1):48-59. [doi:10.1016/j.jcat.2009.12.006]

Li, Z., Tian, S., Wang, H., et al., 2004. Plasma treatment of Ni catalyst via a corona discharge. Journal of Molecular Catalysis A: Chemical, 211(1-2):149-153. [doi:10. 1016/j.molcata.2003.10.003]

Liu, C.J., Vissokov, G.P., Jang, B.W.L., 2002. Catalyst preparation using plasma technologies. Catalysis Today, 72:173-184. [doi:10.1016/S0920-5861(01)00491-6]

Liu, X.H., 2011. Aqueous-phase Reforming of Ethylene Glyeol to Hydrogen on Supported Platinum Catalysts. $\mathrm{PhD}$ Thesis, East China University of Science and Technology, Shanghai, China (in Chinese).

Liu, X.H., Shen, K., Wang, Y.G., et al., 2008. Preparation and catalytic properties of $\mathrm{Pt}$ supported $\mathrm{Fe}-\mathrm{Cr}$ mixed oxide catalysts in the aqueous-phase reforming of ethylene glycol. Catalysis Communications, 9(14):23162318. [doi:10.1016/j.catcom.2008.05.035]

Luo, N., Fu, X., Cao, F., et al., 2008. Glycerol aqueous phase reforming for hydrogen generation over Pt catalysteffect of catalyst composition and reaction conditions. Fuel, 87(17-18):3483-3489. [doi:10.1016/j.fuel.2008.06. 021]

Luo, N., Ouyang, K., Cao, F., et al., 2010. Hydrogen generation from liquid reforming of glycerin over Ni-Co bimetallic catalyst. Biomass and Bioenergy, 34(4):489495. [doi:10.1016/j.biombioe.2009.12.013]

Manfro, R.L., Da Costa, A.F., Ribeiro, N.F., et al., 2011. Hydrogen production by aqueous-phase reforming of glycerol over nickel catalysts supported on $\mathrm{CeO}_{2}$. Fuel Processing Technology, 92(3):330-335. [doi:10.1016/j. fuproc.2010.09.024]
Menezes, A.O., Rodrigues, M.T., Zimmaro, A., et al., 2011. Production of renewable hydrogen from aqueous-phase reforming of glycerol over Pt catalysts supported on different oxides. Renewable Energy, 36(2):595-599. [doi:10.1016/j.renene.2010.08.004]

Meryemoglu, B., Kaya, B., Irmak, S., et al., 2012. Comparison of batch aqueous-phase reforming of glycerol and lignocellulosic biomass hydrolysate. Fuel, 97:241-244. [doi:10.1016/j.fuel.2012.02.011]

Nozawa, T., Mizukoshi, Y., Yoshida, A., et al., 2014. Aqueous phase reforming of ethanol and acetic acid over $\mathrm{TiO}_{2}$ supported $\mathrm{Ru}$ catalysts. Applied Catalysis B: Environmental, 146:221-226. [doi:10.1016/j.apcatb.2013. 06.017]

Özgür, D.Ö., Uysal, B.Z., 2011. Hydrogen production by aqueous phase catalytic reforming of glycerine. Biomass and Bioenergy, 35(2):822-826. [doi:10.1016/j.biombioe. 2010.11.012]

Pagliaro, M., Ciriminna, R., Kimura, H., et al., 2007. From glycerol to value-added products. Angewandte Chemie International Edition, 46(24):4434-4440. [doi:10.1002/ anie.200604694]

Pan, G., Ni, Z., Cao, F., et al., 2012. Hydrogen production from aqueous-phase reforming of ethylene glycol over $\mathrm{Ni} / \mathrm{Sn} / \mathrm{Al}$ hydrotalcite derived catalysts. Applied Clay Science, 58:108-113. [doi:10.1016/j.clay.2012.01.023]

Roy, B., Loganathan, K., Pham, H., et al., 2010. Surface modification of solution combustion synthesized $\mathrm{Ni} / \mathrm{Al}_{2} \mathrm{O}_{3}$ catalyst for aqueous-phase reforming of ethanol. International Journal of Hydrogen Energy, 35(21):11700-11708. [doi:10.1016/j.ijhydene.2010.07. 167]

Roy, B., Sullivan, H., Leclerc, C.A., 2011. Aqueous-phase reforming of $n$-BuOH over $\mathrm{Ni} / \mathrm{Al}_{2} \mathrm{O}_{3}$ and $\mathrm{Ni} / \mathrm{CeO}_{2}$ catalysts. Journal of Power Sources, 196(24):1065210657. [doi:10.1016/j.jpowsour.2011.08.093]

Roy, B., Martinez, U., Loganathan, K., et al., 2012a. Effect of preparation methods on the performance of $\mathrm{Ni} / \mathrm{Al}_{2} \mathrm{O}_{3}$ catalysts for aqueous-phase reforming of ethanol: Part Icatalytic activity. International Journal of Hydrogen Energy, 37(10):8143-8153. [doi:10.1016/j.ijhydene.2012. 02.056]

Roy, B., Artyushkova, K., Pham, H., et al., 2012b. Effect of preparation method on the performance of the $\mathrm{Ni} / \mathrm{Al}_{2} \mathrm{O}_{3}$ catalysts for aqueous-phase reforming of ethanol: Part IIcharacterization. International Journal of Hydrogen Energy, 37(24):18815-18826. [doi:10.1016/j.ijhydene. 2012.09.098]

Shabaker, J.W., Dumesic, J.A., 2004. Kinetics of aqueousphase reforming of oxygenated hydrocarbons: $\mathrm{Pt} / \mathrm{Al}_{2} \mathrm{O}_{3}$ and Sn-modified Ni catalysts. Industrial \& Engineering Chemistry Research, 43(12):3105-3112. [doi:10.1021/ ie049852o]

Shabaker, J.W., Davda, R.R., Huber, G.W., et al., 2003. Aqueous-phase reforming of methanol and ethylene glycol over alumina-supported platinum catalysts. 
Journal of Catalysis, 215(2):344-352. [doi:10.1016/ S0021-9517(03)00032-0]

Shabaker, J.W., Huber, G.W., Dumesic, J.A., 2004. Aqueousphase reforming of oxygenated hydrocarbons over Snmodified Ni catalysts. Journal of Catalysis, 222(1):180191. [doi:10.1016/j.jcat.2003.10.022]

Shabaker, J.W., Simonetti, D.A., Cortright, R.D., et al., 2005. Sn-modified Ni catalysts for aqueous-phase reforming: characterization and deactivation studies. Journal of Catalysis, 231(1):67-76. [doi:10.1016/j.jcat.2005.01.019]

Sjöström, E., 1993. Wood Chemistry: Fundamentals and Applications. Gulf Professional Publishing, Houston.

Skoplyak, O., Barteau, M.A., Chen, J.G., 2009. Comparison of $\mathrm{H}_{2}$ production from ethanol and ethylene glycol on $\mathrm{M} / \mathrm{Pt}$ (111) (M=Ni, Fe, Ti) bimetallic surfaces. Catalysis Today, 147(2):150-157. [doi:10.1016/j.cattod.2008.12. 005]

Tang, Z., Monroe, J., Dong, J., et al., 2009. Platinum-loaded $\mathrm{NaY}$ zeolite for aqueous-phase reforming of methanol and ethanol to hydrogen. Industrial \& Engineering Chemistry Research, 48(5):2728-2733. [doi:10.1021/ ie801222f]

Tanksale, A., Beltramini, J., Dumesic, J., et al., 2008. Effect of $\mathrm{Pt}$ and $\mathrm{Pd}$ promoter on $\mathrm{Ni}$ supported catalystsATPR/TPO/TPD and microcalorimetry study. Journal of Catalysis, 258(2):366-377. [doi:10.1016/j.jcat.2008.06. 024]

Tanksale, A., Zhou, C., Beltramini, J., et al., 2009. Hydrogen production by aqueous phase reforming of sorbitol using bimetallic Ni-Pt catalysts: metal support interaction. Journal of Inclusion Phenomena and Macrocyclic Chemistry, 65(1-2):83-88. [doi:10.1007/s10847-0099618-6]

Tokarev, A., Kirilin, A., Murzina, E., et al., 2010. The role of bio-ethanol in aqueous phase reforming to sustainable hydrogen. International Journal of Hydrogen Energy, 35(22):12642-12649. [doi:10.1016/j.ijhydene.2010.07. $118]$

Tuza, P.V., Manfro, R.L., Ribeiro, N.F., et al., 2013. Production of renewable hydrogen by aqueous-phase reforming of glycerol over $\mathrm{Ni}-\mathrm{Cu}$ catalysts derived from hydrotalcite precursors. Renewable Energy, 50:408-414. [doi:10.1016/j.renene.2012.07.006]

Vannice, M., 1977. The catalytic synthesis of hydrocarbons from $\mathrm{H}_{2} \mathrm{CO}$ mixtures over the Group VIII metals: V. The catalytic behavior of silica-supported metals. Journal of Catalysis, 50(2):228-236. [doi:10.1016/0021-9517(77) 90031-8]

Wang, X., Li, N., Pfefferle, L.D., et al., 2009. Pt-Co bimetallic catalyst supported on single walled carbon nanotube: XAS and aqueous phase reforming activity studies. Catalysis Today, 146(1-2):160-165. [doi:10. 1016/j.cattod.2009.02.010]

Wawrzetz, A., Peng, B., Hrabar, A., et al., 2010. Towards understanding the bifunctional hydrodeoxygenation and aqueous phase reforming of glycerol. Journal of
Catalysis, 269(2):411-420. [doi:10.1016/j.jcat.2009.11. 027]

Wen, G.D., Xu, Y.P., Ma, H.J., et al., 2008. Production of hydrogen by aqueous-phase reforming of glycerol. International Journal of Hydrogen Energy, 33(22):66576666. [doi:10.1016/j.ijhydene.2008.07.072]

Wen, G.D., Xu, Y.P., Wei, Y., et al., 2009. Hydrogen production by aqueous-phase reforming of biomass over supported Pt catalysts. Chinese Journal of Catalysis, 30(8):830-835. [doi:10.1016/j.ijhydene.2010.09.094]

Wen, Z., Yu, X., Tu, S.T., et al., 2010. Synthesis of biodiesel from vegetable oil with methanol catalyzed by Li-doped magnesium oxide catalysts. Applied Energy, 87(3):743748. [doi:10.1016/j.apenergy.2009.09.013]

Xie, F., Chu, X., Hu, H., et al., 2006. Characterization and catalytic properties of Sn-modified rapidly quenched skeletal $\mathrm{Ni}$ catalysts in aqueous-phase reforming of ethylene glycol. Journal of Catalysis, 241(1):211-220. [doi:10.1016/j.jcat.2006.05.001]

Yagodovskaya, T., Lunin, V., 1997. Surface modification of cements and zeolite catalysts by glow discharge. Russian Journal of Physical Chemistry, 71(5):775-786.

Zhang, L., Karim, A.M., Engelhard, M.H., et al., 2012. Correlation of Pt-Re surface properties with reaction pathways for the aqueous-phase reforming of glycerol. Journal of Catalysis, 287:37-43. [doi:10.1016/j.jcat. 2011.11.015]

Zhang, Y., Chu, W., Cao, W., et al., 2000. A plasmaactivated $\mathrm{Ni} / \alpha-\mathrm{Al}_{2} \mathrm{O}_{3}$ catalyst for the conversion of $\mathrm{CH}_{4}$ to syngas. Plasma Chemistry and Plasma Processing, 20(1):137-144. [doi:10.1023/A:1006978012228]

Zhu, L., Guo, P., Chu, X., et al., 2008. An environmentally benign and catalytically efficient non-pyrophoric $\mathrm{Ni}$ catalyst for aqueous-phase reforming of ethylene glycol. Green Chemistry, 10(12):1323-1330. [doi:10.1039/ b808190e]

\section{中文概要}

\section{题 目: 生物质衍生醇类水相重整制氢研究进展}

概 要: 氢气作为一种清洁、高效的可持续能源, 近年来 得到了广泛关注。水相重整技术以生物质衍生 醇类制备氢气，具有来源广泛、反应条件温 和、运行成本较低等优点, 相较于其他制氢方 法更有优势。本文详细阐述生物质衍生醇类水 相重整制氢的研究进展, 同时讨论不同催化剂 的反应机理。Pt 系催化剂表现出较高的氢气选 择性, 但是醇类转化率较低。 $\mathrm{Ni}$ 系催化剂反应 活性和转化率均较高, 但仍存在氢气选择性和 氢气产率较低等问题。

关键词: 生物质; 醇类; 制氢; 水相重整制氢; 反应机 理; 催化剂 